\title{
The sign switch effect of macroeconomic news in foreign exchange markets
}

\author{
Walid Ben Omrane ${ }^{\mathrm{a}}$, Tanseli Savaşer ${ }^{\mathrm{b}, *}$ \\ ${ }^{a}$ Goodman School of Business, Brock University, 500 Glenridge Ave, St. Catharines, ON, Canada \\ ${ }^{\mathrm{b}}$ Faculty of Business Administration, Bilkent University, 06800 Ankara, Turkey
}

\section{A R T I C L E I N F O}

\section{Article history:}

Received 22 October 2015

Accepted 5 July 2016

Available online 14 July 2016

\section{JEL classification:}

F31

F4

G1

Keywords:

Financial crisis

Exchange rates

US dollar

Macroeconomic news

High-frequency data

\begin{abstract}
A B S T R A C T
We examine an unusual episode in the behavior of the euro, pound and yen exchange rate markets when the dollar appreciated (depreciated) against the three major currencies, in response to unfavorable (favorable) US growth news during the global financial crisis. Contrary to the previous findings, we show that, for each currency pair, only a small subset (about a third) of the most significant macro news effects reversed sign, primarily announcements regarding consumption, credit, labor and housing markets. Our results reveal that announcement chronology within a month matters, in that specifically the earliest releases within an indicator category exhibit sign asymmetry.
\end{abstract}

(c) 2016 Elsevier B.V. All rights reserved.

\section{Introduction}

Standard models of exchange rate determination predict that positive (negative) growth news tend to appreciate (depreciate) the value of a country's currency. However, the opposite can also occur, appreciating (depreciating) the exchange rate in response to unfavorable (favorable) growth news, if for example, investors' risk aversion is sufficiently large. Such an unusual behavior of exchange rates has recently occurred during the global financial crisis (Fratzscher, 2009). Using a high frequency dataset of the three major currency pairs (euro-dollar, pound-dollar, yen-dollar), we provide the first intraday analysis of the composition and sources of the sign switch in the exchange-rate response to news coefficients during this period. Contrary to the previous findings which rely on daily returns, we show that, for each currency pair, only a subset (about a third) of the macro indicators' effects reversed sign beginning in 2008, in particular announcements relating to housing, credit and labor markets, which were at the epicenter of the financial crisis. The sign switch effect we document is prevalent in all three markets, yet weaker in the yen-dollar currency pair.

We estimate the conditional mean response of 5-min returns between 2005 and 2012 following Andersen et al. (2003, 2007) and show that the news coefficient sign reversal is strongest for the consumer confidence, consumer price index (CPI), new home sales, housing starts, initial claims, non-farm payroll employment and Fed funds rate announcements,

\footnotetext{
* Corresponding author.

E-mail addresses: wbenomrane@brocku.ca (W. Ben Omrane), tsavaser@bilkent.edu.tr (T. Savaşer).
} 
which are the earliest releases within a month containing information about consumption, real-estate, labor and credit markets. These results indicate a context-specific change in investors' reaction to news and reveal that announcement chronology within an indicator category matters for the sign switch effect to take place. Typically those announcements in a given month that are the earliest releases within an indicator category, which contain incremental information about consumption, real-estate and labor markets reveal sign asymmetry. Our results suggest that, given the sources and evolution of risk during the 2008-2009 financial crisis, investors rationally paid more attention to the signals in the earliest, most informative releases related to consumption, housing, credit and employment to collect new information about the potential changes in the relevant market risks. We also explore various sources of macronews parameter instability suggested by the foreign exchange literature and find that fluctuations in aggregate risk levels, carry trade returns and the Federal Reserve Bank's (Fed) interest rate policy explain most of the variation in news response coefficients.

Many papers have investigated the impact of macroeconomic news on exchange rate markets. However, the literature has not reached a clear consensus on whether the exchange rate return reaction to news varies over time. For example, Andersen et al. (2007), Faust et al. (2007) and Goldberg and Grisse (2013) suggest that time-variation is not a first order issue in foreign exchange rate markets (unlike bond or stock markets) whereas Fratzscher (2009) and Fatum et al. (2010) show that exchange rate reaction to news depends on economic conditions. Bauwens et al. (2005) examine the intraday volatility impact of macroeconomic news, but their dataset is limited in scope including a 26 week period in 2001, which makes it difficult to study time-variance in news effects. Given these mixed results and the limited sample periods used in previous empirical analyses, we contribute to the literature by testing the time-variance in news effects during a more recent and extensive period, which includes the global financial crisis when the risk conditions were significantly elevated.

Perhaps most relevant to our study is the analysis by Fratzscher (2009). Similar to our paper, Fratzscher (2009) explores the behavior of the US dollar during the global financial crisis. However, the focus of Fratzscher (2009) is not the reaction of exchange rates to macroeconomic announcements per se. Rather, it provides an explanation to the general depreciation trend in the global currencies vis-à-vis the US dollar during the crisis by concentrating on the cross-sectional determinants such as countries' foreign exchange (FX) reserves, current account positions and financial exposure vis-à-vis the United States. As a side result, the study also reports that there has been an across the board reversal in the direction of the daily exchange rate reaction to macroeconomic news between July 2008 and January 2009.

In our paper, we take this result a step further and analyze the announcement effects during the entire crisis period using high-frequency exchange rate returns. Contrary to the findings in Fratzscher (2009), however, we show that only a selective group of announcements' coefficients reversed sign during the crisis, primarily news related to housing, credit and labor markets indicating the context-specific nature of the sign switch effect. The difference in our findings largely stems from the window over which we calculate the exchange rate returns.

We use intraday returns because intraday data are more appropriate for investigating announcement effects in currency markets. The advantage of using high frequency exchange rate dataset is that it helps capture the pure announcement effects. Earlier analyses that rely on daily FX returns may miss the variation in news response coefficients given the rapid response of exchange rate returns to news. Previous literature shows that the conditional mean adjustments of exchange rates to macroeconomic news occur quickly, within a few minutes following the news announcement, effectively amounting to jumps (Andersen et al., 2003, 2007). Therefore, in markets where return reaction to announcements is rapid (as in FX markets), the use of wider (daily) return windows may contaminate the announcement effects since longer intervals may include other events as well. This would reduce the public signal to noise ratio and introduce bias in the daily news response coefficients. To mitigate this bias, many studies in the FX literature use high-frequency data to examine the announcement effects (e.g. Andersen et al., 2003; Andersen et al., 2007; Bauwens et al., 2005; Faust et al., 2007; Goldberg and Grisse, 2013; Fatum et al., 2010).

In addition, the analysis in Fratzscher (2009) spans the period between 1994 and January 2009, hence does not cover the entire crisis period. According to the NBER, the economic contraction that began with the US financial crisis lasted until the end of June 2009. Therefore, although the sample period in Fratzscher (2009) is longer than ours, it is not enough to investigate the crisis episode fully as it lacks 6 months of the crisis period. Since our paper's focus and contribution is the investigation of the unusual sign reversal in news effects that took place in major currency markets during the US financial crisis, including the entire crisis episode in the investigation is critical for our analysis.

To explore the possible sources of the change in news coefficient signs over our sample period, we consider various explanations for time-variant news effects suggested by the literature. Specifically, we examine the importance of the changes in (1) economic conditions, (2) central bank interest rate policies and (3) aggregate risk levels. As noted previously in the literature, the 2008 global financial crisis is directly related to the US monetary conditions and the fluctuations in risk aversion and uncertainty (Bekaert et al., 2012; Bruno and Shin, 2013; Miranda-Agrippino and Rey, 2012). There are different channels through which risk can affect the behavior of news response coefficients. The first channel involves the fluctuations in the risk premium associated with holding non-US dollar currency assets (Faust et al., 2007) and investors turning to safe, lowreturn US dollar denominated assets in response to the sharp increase in economic uncertainty (McCauley and McGuire, 2009; Gourinchas et al., 2010). Considering the US role as the global insurer in the international monetary system, investors' flight to quality due to an increase in risk aversion is likely to result in a reversal of the relationship between the macronews and exchange rates during crisis times, in that bad (good) US growth news signal even worse (better) global growth prospects, which impact other countries' currencies more negatively (positively) than the US dollar, and hence appreciate (depreciate) the dollar. 
Similarly, business cycles can also introduce a degree of time variation in how exchange rates react to news. As the economy gets closer to or farther away from the central bank targets of inflation and output, the weight investors attach to a given piece of news might vary due to perceived future changes in monetary policy (Goldberg and Grisse, 2013). Contrary to this, however, Bacchetta and van Wincoop $(2004,2011)$ argue that rational investors tend to search for a "scapegoat" fundamental and attach a higher weight to it when their beliefs about the long-run value of the exchange rate conflict with the short-run movements, and the "scapegoat" fundamental's behavior is in line with the short-run exchange rate trend. Hence, while scapegoat theory implies ad hoc shifts in investor focus, Goldberg and Grisse (2013) emphasize the role of business cycles and context-specific policy decisions in generating dynamic news effects.

To account for the sources of time variation in news effects, we augment our conditional mean model by including various measures of risk, interest rates and carry trade returns. Our results suggest that the fluctuation in the aggregate risk level is a particularly important contributor to the change in the news coefficient signs, specifically for consumption, realestate and employment related news items. We find that, as market risk increases, the dollar appreciation in response to a unit of positive US growth news dampens. We also find that the fluctuations in carry trade returns are significant contributors to time-varying news effects especially in the dollar-yen market. In addition, our results show that the appreciation of the dollar in response to a unit of positive US growth news is intensified as long-term interest rates increase, which is consistent with the predictions of the standard exchange rate determination models.

Furthermore, given the more gradual and persistent the volatility reaction to macroeconomic news, we test the timevariance in news effects by analyzing the conditional variance of exchange rate returns following the news announcements over our sample period. We find that consistent with the increase in uncertainty, the volatility response to majority of the US news releases increases during the global financial crisis.

The contributions of our paper are the following: (1) Contrary to the previous studies which rely on daily returns, we show that only a small subset of news items exhibit coefficient sign asymmetry. (2) The news effects that switch sign are those that are related to consumption, housing, labor and credit markets, which were at the epicenter of the crisis, indicating a context-specific shift in investor reaction. (3) Announcement timing matters for the sign switch effect in that sign reversal is most prevalent for the earliest releases within a month containing incremental information about consumption and realestate market risks. (4) The fluctuations in the market risk is the primary contributor to the sign reversal in news effects. (5) The volatility reaction to news is larger in the crisis period for a majority of the US announcements.

Overall, we find that investor sentiment and economic conditions have an important impact on currency return behavior. During periods of elevated risk, traditional relationships between macroeconomic fundamentals and exchange rates may not hold. Investors and financial institutions that hold and trade international assets as well as the managers of non-financial corporations that participate in FX markets due to the nature and requirements of their businesses (such as importing, exporting and hedging activities) should take into account the time-variant nature of announcement effects.

The rest of the paper proceeds as follows: Section 2 describes the datasets and the econometric methodology. In Section 3, we present the results documenting the sign switch effect based on the conditional mean return and volatility models. Section 4 introduces results from the augmented model, which includes the determinants of the sign switch effect. Section 5 presents the findings regarding the volatility reaction to news and the final section concludes.

\section{Data and methodology}

\subsection{Exchange rate and macroeconomic news dataset}

Our 5-min intraday exchange rate dataset, provided by Hotspot FXi, consists of euro-dollar, pound-dollar and yen-dollar currency pairs and spans eight years from January 1, 2005 to December 31, 2012. It contains tradable (as opposed to indicative) quotes for the bid and ask spot exchange rates. We compute the midpoint price by taking the average of bid and ask prices. At the end of each 5-min interval, we use the closest previous tick to select the relevant price. Next, the return $\left(R_{t, n}\right)$ at time interval $n$ on day $t$ is computed as the difference between the logarithms of the prices at times $n-1$ and $n$, multiplied by 100 . We define a trading day to start at 00:00 EST and end at 23:55 EST. We exclude weekends and holidays due to trading activity. After these filters, the total number of returns in our sample reduces to 514,724 (Table 1).

Our news dataset includes the announced values of the US macroeconomic fundamentals along with the forecasts of the traders in anticipation of those releases. ${ }^{1}$ To measure the unexpected component of each announcement, we calculate the standardized news surprise as the difference between the announced value of the indicator and its median forecast from the MMS survey divided by the sample standard deviation of this difference. We cover all relevant US announcements that influence the currency markets following Andersen et al. (2003, 2007) and Fatum et al. (2010). The list includes the three GDP reports (advance, second and third), non-farm payroll employment, initial jobless claims, industrial production, capacity utilization, retail sales, personal income, consumer spending, construction spending, new home sales, durable goods orders, factory orders, business inventories, trade balance, producer price index, consumer price index, consumer confidence index, ISM index, housing starts, index of leading indicators, treasury budget and target Federal funds rate releases. In line with the literature, we group

\footnotetext{
${ }^{1}$ All news data are collected by the Money Market Services (MMS) provided by Action Economics, and Bloomberg.
} 
Table 1

Summary Statistics. This table reports the summary statistics of 5-min exchange rate returns between January 1 , 2005 and December 31,2012 . The dataset is provided by HotspotFXi and contains tradeable bid-ask prices. The return at time $t\left(R_{t}\right)$ is computed as the difference between the logarithms of the midpoint prices at times t-1 and t, multiplied by 100. Trading days start at 00:00 EST and end at 23:55 EST. We also exclude weekends and holidays because of low trading activity, which reduces the total number of returns in our sample to 514,724 .

\begin{tabular}{|c|c|c|c|}
\hline & \$/EUR returns & \$/GBP returns & \$/JPY returns \\
\hline Mean & 0.00005 & 0.00005 & 0.00000 \\
\hline Median & 0.0000 & 0.0000 & 0.0000 \\
\hline Maximum & 1.121 & 1.172 & 1.792 \\
\hline Minimum & -1.129 & -1.211 & -2.871 \\
\hline Std. Dev. & 0.041 & 0.041 & 0.043 \\
\hline Skewness & 0.106 & -0.121 & -0.294 \\
\hline Kurtosis & 19.94 & 24.76 & 86.43 \\
\hline
\end{tabular}

the announcements into nine indicator categories: real activity, employment, consumption, investment, net exports, government purchases, prices, central bank policy rate and forward-looking news (Table 2).

To capture the unscheduled news events that occurred over our sample period, we construct an indicator variable that takes on the value " 1 " on the dates when there is an unanticipated market event or a policy action announced by a regulatory authority. We use the list of events provided by the NY Fed's Financial Turmoil Timeline as our guide (NY Fed, 2011). ${ }^{2}$ The unscheduled news indicator includes releases by the Treasury, the Federal Reserve, foreign central banks, and other regulatory institutions (e.g. the introduction of the economic stimulus act, the establishment of the swap lines and other capital injections) as well as unanticipated market events such as the loss reports by Bear Stearns, Lehman Brothers and General Motors bankruptcies and credit agency downgrades.

Our sample spans the 2005-2012 period which includes the entire crisis episode. Following Melvin and Taylor (2009), we assume the crisis started in August 2007 when the first signs of the financial market turmoil emerged and end on June 30th, 2009. We also test for the sensitivity of our findings to the changes in the crisis definition and consider alternative start and end dates including the recession dates determined by the National Bureau of Economic Research (NBER) ${ }^{3}$ and Fratzscher (2009).

\subsection{Econometric methodology}

Previous literature shows that the conditional mean adjustments of exchange rates to macroeconomic news occur rapidly, within a few minutes following the news announcement, effectively amounting to jumps (Andersen et al., 2003, 2007). Based on this stylized fact and the framework suggested in Andersen et al. (2003), we estimate the conditional mean response of the 5-min returns $\left(\mathrm{R}_{\mathrm{t}, \mathrm{n}}\right)$ to scheduled US macroeconomic announcements, $k$, as follows:

$$
R_{t, n}=\mu+\sum_{i=1}^{I} \alpha_{i} R_{t, n-i}+\sum_{k=1}^{K} \sum_{j=0}^{J} \beta_{k j} S_{k, t, n-j}+\varepsilon_{t, n}
$$

where $n=1, \ldots, N$ is the intraday interval on day $\mathrm{t}$ and $S_{k, t, n}$ is the surprise component of news $k$ corresponding to interval $\mathrm{n}$ on day $t$, which is equal to the difference between the announced value of the news indicator $\left(A_{k t}\right)$ and its median forecast from the MMS survey $\left(F_{k t}\right)$ divided by the sample standard deviation of $\left(A_{k t}-F_{k t}\right)$. K denotes the total number of the different types of scheduled US macroeconomic news indicators in our sample $(K=24)$. We have a total number of 514,724 observations and choose $\mathrm{I}=4$ and $\mathrm{J}=2$ based on the Schwarz and Akaike information criteria.

To examine the exchange rates' conditional volatility response to macroeconomic news, we use the following model:

$$
\left|\varepsilon_{t, n}\right|=\mu+\delta_{1} n+\delta_{2} n^{2}+\omega \frac{\hat{\sigma}_{t}}{\sqrt{N}}+\sum_{l=1}^{L} \lambda_{l} I_{l, t, n}+\sum_{p=1}^{P}\left(\delta_{c, p} \cos \left(\frac{2 \pi p}{N} n\right)+\delta_{s, p} \sin \left(\frac{2 \pi p}{N} n\right)\right)+\sum_{k=1}^{K} \sum_{j=0}^{J} \rho_{k j} S_{k, t, n-j}+\varepsilon_{t, n}^{\prime} .
$$

where we control for the cyclical seasonality pattern using the Flexible Fourier Form (the sum of sine and cosine terms) and the one-step ahead volatility GARCH $(1,1) \hat{\sigma}_{t}$. In addition, $I_{l}$ captures the Japanese lunch hour, Japanese open, and the US late afternoon.

We estimate the mean Eq. (1) using a two-step weighted least-squares (WLS) procedure. First, we estimate the mean equation by ordinary least-squares method, and then we estimate the volatility Eq. (2), which we use to perform the weighted least-squares estimation of Eq. (1). ${ }^{4}$

In contrast to the documented rapid conditional mean adjustment of exchange rates to news, previous studies find that the conditional variance adjustment to macroeconomic news surprises is more gradual, with complete adjustment occurring

\footnotetext{
${ }^{2}$ For a full list of events and policy actions included in our analysis, see the NYFed's Financial Turmoil Timeline (2011)

3 http://www.nber.org/cycles/cyclesmain.html.

${ }^{4}$ See Andersen et al. (2003) for more details about the WLS procedure.
} 
Table 2

US macroeconomic announcements. There are 24 different announcements that are grouped into nine indicator categories: Real activity, employment, consumption, investment, net exports, government purchases, prices, central bank policy rate and forward-looking news. GDP reports are released quarterly. The target Fed funds rate is released every six weeks. Initial jobless claims are announced weekly.

\begin{tabular}{lll}
\hline Indicator Group & Announcement & Source \\
\hline Real activity & GDP advance report & Bureau of Economic Analysis \\
Real activity & GDP second report & Bureau of Economic Analysis \\
Real activity & GDP third report & Bureau of Economic Analysis \\
Real activity & Capacity utilization & Federal Reserve Board \\
Real activity & Industrial production & Federal Reserve Board \\
Real activity & Personal income & Bureau of Economic Analysis \\
Real activity & Retail sales & Bureau of the Census \\
Consumption & New home sales & Bureau of the Census \\
Consumption & Personal expenditure & Bureau of Economic Analysis \\
Investment & Business inventories & Bureau of the Census \\
Investment & Construction spending & Bureau of the Census \\
Investment & Durable orders & Bureau of the Census \\
Investment & Factory orders & Bureau of the Census \\
Price & Consumer Price Index & Bureau of Labor Statistics \\
Price & Producer Price Index & Bureau of Labor Statistics \\
Forward-looking & Consumer confidence & Conference Board \\
Forward-looking & Housing starts & Bureau of the Census \\
Forward-looking & ISM (Manufacturing) & Institute for Supply Management \\
Forward-looking & Leading indicators & Conference Board \\
Employment & Initial claims & Employment and Training Administration \\
Employment & Nonfarm payrolls & Bureau of Labor Statistics \\
FOMC & Fed funds rate & Federal Reserve Board \\
Net exports & Trade balance & Bureau of Economic Analysis \\
Government & Treasury budget & Financial Management Service \\
\hline
\end{tabular}

within two hours after the news release (Andersen et al., 2003; Bauwens et al., 2005; Dominguez and Panthaki, 2006). To control for such a persistence, we impose a polynomial structure on the response pattern associated with the news coefficient, $\rho_{k j}$, where $J$ denotes the response window $(j=1,2, \ldots, J)$. The polynomial specification ensures that the response patterns are fully incorporated within the response horizon, $J$ :

$$
\lambda_{j}=\tau_{1}\left(1-\left(\frac{j}{J}\right)^{3}\right)+\tau_{2}\left(1-\left(\frac{j}{J}\right)^{2}\right) j+\tau_{3}\left(1-\left(\frac{j}{J}\right)\right) j^{2} .
$$

Here, $\lambda_{j}$ represents the fitted values corresponding to the centered average absolute returns regression on the polynomial exogenous variables. ${ }^{5}$

To analyze the conditional mean adjustment of exchange rates to news during the crisis period, we construct an indicator variable $\left(D_{\text {crisis }}\right)$, which takes on the value " 1 " for the observations between during the crisis and " 0 " else. To denote intervals outside the crisis period, we define $\left(D_{\text {no-crisis }}\right)$ as $\left(1-D_{\text {crisis }}\right)$. Then, we interact the news surprise variables with the indicator variables $\left(D_{\text {crisis }}\right)$ and $\left(D_{\text {no-crisis }}\right)$ to test the presence of time-variant news effects:

$$
R_{t, n}=\lambda+\sum_{i=1}^{I} \phi_{i} R_{t, n-i}+\sum_{k=1}^{K} \sum_{j=0}^{J} \varphi_{k j} S_{k, t, n-j} D_{\text {nocrisis }}+\sum_{k=1}^{K} \sum_{j=0}^{J} \gamma_{k j} S_{k, t, n-j} D_{\text {crisis }}+\Omega U N S C_{t, n}+v_{t, n} .
$$

We also include an unscheduled news indicator variable (UNSC ${ }_{t}$ ) in Eq. (4), which takes on the value "1" whenever there is an unanticipated market event or a policy action announcement by a regulatory authority such as the Fed, SEC or the ECB. The New York Fed Financial Turmoil Timeline details the list of events included in our analysis (Federal Reserve Bank, 2011).

In parallel with the conditional mean model, in order to investigate the presence of time-variant exchange rate volatility reaction to news over our sample period, we interact the news surprise variables in the volatility model with the crisis indicator variables:

$$
\begin{aligned}
\left|v_{t, n}\right|= & \mu+\delta_{1} n+\delta_{2} n^{2}+\omega \frac{\hat{\sigma}_{t}}{\sqrt{N}}+\sum_{l=1}^{L} \lambda_{l} I_{l, t, n}+\sum_{p=1}^{P}\left(\delta_{c, p} \cos \left(\frac{2 \pi p}{N} n\right)+\delta_{s, p} \sin \left(\frac{2 \pi p}{N} n\right)\right)+\sum_{k=1}^{K} \sum_{j=0}^{J} \rho_{k j}^{\prime} S_{k, t, n-j} D_{\text {nocrisis }} \\
& +\sum_{k=1}^{K} \sum_{j=0}^{J} \rho_{k j}^{\prime \prime} S_{k, t, n-j} D_{\text {crisis }}+v_{t, n}^{\prime}
\end{aligned}
$$

\footnotetext{
${ }^{5}$ Centered average absolute returns are computed as the average absolute returns at each time interval just after the news announcements minus the average absolute return computed over the whole sample.
} 
Finally, in order to examine the sources of time variation in news effects, we augment our baseline conditional mean Eq. (1) by including interactions of the surprise variables with three factors that the previous literature identifies as potential contributors to time-variant news effects in currency markets. These factors include (i) the aggregate risk level in the economy $\left(V_{I X}\right)$, (ii) the interest rate policies followed by the Fed $\left(\right.$ LTR $\left._{t}\right)$ and (iii) the fluctuations in carry trade returns $\left(A U D_{t}\right)$ :

$$
\begin{aligned}
R_{t, n}= & \lambda^{\prime}+\sum_{i=1}^{I} \phi_{i}^{\prime} R_{t, n-i}+\sum_{k=1}^{K} \sum_{j=0}^{J} \varphi_{k j}^{\prime} S_{k, t, n-j}+\sum_{k=1}^{K} \sum_{j=0}^{J} \gamma_{V I X, k j} S_{k, t, n-j} V I X_{t, n}+\sum_{k=1}^{K} \sum_{j=0}^{J} \gamma_{A U D, k j} S_{k, t, n-j} A U D_{t, n} \\
& +\sum_{k=1}^{K} \sum_{j=0}^{J} \gamma_{L T R, k j} S_{k, t, n-j} L T R_{t, n}+\Omega U N S C_{t, n}+\kappa_{t, n}
\end{aligned}
$$

Our measure of risk is the implied volatility of the S\&P 500 index options, which is a standard measure used in the literature (Bekaert et al., 2012; Goldberg and Grisse, 2013; De Bock and De Carvalho, 2013). The index is quoted in annualized percentage point terms and represents the market's expectation of the stock market volatility over the next 30-day period. Next, we consider the effect of the Federal Reserve Bank's interest rate policies. In particular, when the Fed lowered the short term interest rates to zero in order to combat the recessionary effects of the financial crisis, markets began to pay less attention to short-term yields, rendering the long-term rates the effective tool for monetary policy (Swanson and Williams, 2013, 2014). For this reason, we use the 10-year real treasury yields as the relevant measure of interest rate policy. To capture the effect of the changes in the profitability and the direction of the carry trade flows, we include the 5-min Australian dollarJapanese yen exchange rates in our augmented model. This is a popular currency pair among the G-10 carry trade investors due to its liquidity (De Bock and De Carvalho, 2013). In order to assess the relative contribution of each factor and enable direct comparison between the coefficient estimates, we center and standardize the values of $\left(\right.$ VIX $\left._{t}\right)$, ( LTR $\left._{t}\right)$ and $\left(A_{U} D_{t}\right)$. For instance, when $\mathrm{VIX}_{\mathrm{t}}$ is equal to zero, the volatility index is at its sample average. Table 3 presents the summary statistics of these variables.

\section{Intraday analysis of the sign switch effect: composition and characteristics}

Standard models of exchange rate determination predict that positive (negative) US growth news tend to appreciate (depreciate) the dollar. Earlier empirical intraday studies support these predictions and show that stronger than expected economic activity news tends to appreciate a country's currency. ${ }^{6}$ Our full sample analysis, which focuses on the 5-min conditional mean adjustment of currency returns over the 2005-2012 period confirms this finding (Eq. (1)). For instance, a one standard deviation positive (negative) US non-farm payroll employment surprise appreciates (depreciates) the dollar against the yen by 20.9 basis points (Table 4). This is an economically and statistically significant effect given the conventional dollar-yen interdealer spreads, which average around 1.5 basis points over our sample period (Mancini et al., 2013).

Yet, the relevance of macro news for currency markets can vary over time (Bacchetta and van Wincoop, 2004, 2011; Cheung and Chinn, 2001; Rossi, 2006; Sarno and Valente, 2009). In particular, business cycles, sharp fluctuations in risk conditions and central bank policies can generate time-variant news effects in currency markets. For instance, Fatum et al. (2010) document substantial asymmetry over the business cycle in the dollar-yen market between 1999 and 2006 . Contrary to these results, however, Faust et al. (2007) and Andersen et al. (2007) indicate relatively stable exchange rate reaction to news across different states of the economy.

Given the mixed results in the literature, we investigate the stability of the relationship between macro news and exchange rates using a more recent and comprehensive news dataset. Our data comprise all major scheduled and unscheduled US macroeconomic news between 2005 and 2012, an interval which includes the financial market turmoil as well as the expansionary periods that precede and follow it. Following Melvin and Taylor (2009), we date the crisis in the currency markets as the interval between August 2007 and July 2009 and estimate separate news effect coefficients for the crisis and the no-crisis periods (Eq. (2)). We later test the sensitivity of our results to the changes in the crisis definition.

Our findings confirm the time-varying nature of the exchange-rate reaction to news. Specifically, we show that the sign as well as the magnitude of the news effect coefficients varies over time. Over our sample period, a positive one standard deviation surprise in new home sales leads to an appreciation of the dollar against the euro by 4.5 basis points in expansionary times while the same surprise leads to a depreciation of the dollar by 6.9 basis points in the crisis period (Table 5). Consumer confidence figures are similar in that, in response to a shock of equal magnitude, the dollar appreciates against the yen by 4.9 basis points in expansionary periods and depreciates by 4.5 basis points during the crisis. These differences are statistically significant at the five percent level. Considering the interdealer spreads in the euro-dollar and dollar-yen markets, which average around one basis point over our sample period, the estimated coefficients represent statistically and economically meaningful variations in news impact (Mancini et al., 2013).

Our analysis shows that for each currency pair, only a small subset of the macro indicators' effects reversed sign during the financial turmoil, in particular announcements relating to housing, credit and labor markets, which were at the epicenter of the crisis. In both the pound-dollar and the euro-dollar markets, about seven out of the 24 different macroeconomic

\footnotetext{
${ }^{6}$ For an extensive literature survey on the documented announcement effects in currency markets, see Neely and Dey (2010).
} 
Table 3

Summary statistics: Augmented model variables. This table reports the summary statistics of the implied volatility of the S\&P 500 index options (VIX), the $10-$ year real treasury rate (LTR) and the 5-min Australian dollar-Japanese yen exchange rates (AUD) used in the augmented model. The data span the period between January 1, 2005 and December 31, 2012. Chicago Board Options Exchange provides the volatility index (VIX), which is quoted in annualized percentage point terms and represents the market's expectation of the stock market volatility over the next 30-day period. The 10-year real treasury rates (LTR) are from the Board of Governors of the Federal Reserve System. The 5-min Australian dollar-Japanese yen exchange rates (AUD) are quoted per Australian dollar and computed using the dataset provided by HotspotFXi. We center and standardize the variables around their respective sample means and use the standardized versions in the estimation of Eq. (3).

\begin{tabular}{llllll}
\hline & VIX & LTR & AUD & VIX centered & ATR centered \\
\hline Mean & 21.46 & 4.04 & 84.61 & 0.00 & 0.00 \\
Median & 18.53 & 4.25 & 83.74 & -0.28 & 0.00 \\
Maximum & 80.86 & 5.41 & 107.83 & 5.61 & -0.10 \\
Minimum & 9.89 & 2.06 & 55.34 & -1.09 & 1.63 \\
Std. Dev. & 10.59 & 0.84 & 9.17 & -2.37 \\
Skewness & 2.02 & -0.70 & -0.16 & 2.02 & 1.00 \\
Kurtosis & 8.26 & 2.48 & 3.80 & 8.26 & -0.70 \\
\hline
\end{tabular}

Table 4

Contemporaneous US news response coefficients. This table reports the contemporaneous US news response coefficients from the mean model based on Eq. (1). For each currency pair, the first column presents the news response coefficient estimates from the whole sample ( $\beta_{\mathrm{k}}$ ) and the second column provides the $p$ values of the individual coefficients.

\begin{tabular}{|c|c|c|c|c|c|c|}
\hline \multirow[b]{2}{*}{ News variables } & \multicolumn{2}{|c|}{ USD/EUR } & \multicolumn{2}{|c|}{ USD/GBP } & \multicolumn{2}{|l|}{ JPY/USD } \\
\hline & $\beta_{\mathrm{k}}$ & $p$-val & $\beta_{\mathrm{k}}$ & $p$-val & $\beta_{\mathrm{k}}$ & $p$-val \\
\hline Capacity utilization & 0.005 & 0.540 & 0.031 & 0.001 & -0.010 & 0.248 \\
\hline GDP advanced report & -0.042 & 0.000 & -0.042 & 0.000 & -0.026 & 0.000 \\
\hline GDP second report & -0.035 & 0.000 & -0.025 & 0.014 & -0.061 & 0.000 \\
\hline GDP third report & -0.023 & 0.007 & 0.021 & 0.005 & -0.062 & 0.000 \\
\hline Industrial production & -0.004 & 0.597 & -0.027 & 0.004 & -0.013 & 0.121 \\
\hline Personal income & 0.005 & 0.334 & 0.010 & 0.030 & 0.000 & 0.967 \\
\hline Retail sales & -0.010 & 0.006 & 0.023 & 0.000 & -0.094 & 0.000 \\
\hline New home sales & -0.042 & 0.000 & -0.030 & 0.000 & -0.072 & 0.000 \\
\hline Personal expenditure & 0.014 & 0.001 & 0.011 & 0.017 & -0.008 & 0.099 \\
\hline Business inventories & -0.010 & 0.011 & -0.016 & 0.000 & 0.002 & 0.704 \\
\hline Construction spending & 0.017 & 0.000 & 0.011 & 0.000 & -0.020 & 0.000 \\
\hline Durable orders & -0.024 & 0.000 & -0.027 & 0.000 & -0.037 & 0.000 \\
\hline Factory orders & -0.022 & 0.000 & -0.012 & 0.004 & -0.032 & 0.000 \\
\hline CPI & 0.013 & 0.002 & 0.024 & 0.000 & -0.012 & 0.008 \\
\hline PPI & -0.020 & 0.000 & -0.047 & 0.000 & -0.032 & 0.000 \\
\hline Consumer confidence & 0.019 & 0.000 & 0.010 & 0.011 & 0.002 & 0.653 \\
\hline Housing starts & -0.004 & 0.419 & 0.000 & 0.959 & -0.030 & 0.000 \\
\hline ISM & -0.025 & 0.000 & -0.015 & 0.000 & -0.092 & 0.000 \\
\hline Leading indicators & -0.001 & 0.791 & 0.021 & 0.000 & -0.025 & 0.000 \\
\hline Initial claims & -0.006 & 0.001 & -0.008 & 0.000 & 0.031 & 0.000 \\
\hline Nonfarm payrolls & -0.048 & 0.000 & -0.069 & 0.000 & -0.209 & 0.000 \\
\hline Fed funds rate & -0.033 & 0.000 & -0.062 & 0.000 & -0.014 & 0.004 \\
\hline Trade balance & -0.054 & 0.000 & -0.044 & 0.000 & -0.061 & 0.000 \\
\hline Treasury budget & 0.007 & 0.169 & 0.000 & 0.991 & 0.007 & 0.120 \\
\hline
\end{tabular}

releases switched sign (Table 5). In the yen-dollar market, fewer announcements' effect (3 out of 24) reversed sign, possibly due to yen's own safe-haven currency status in the international monetary system.

We also investigate the timing of the reversal in the exchange rate reaction to news by focusing on the CPI, consumer confidence and new home sales announcements, which portray the strong sign asymmetry over our sample period. We plot the surprise component of these news releases along with the intraday returns of the three major currency pairs (Figs. 1, 2 and 3) and find that the reversal of the relationship between news surprise and exchange rate returns starts at the beginning of 2008. Therefore, we redefine our currency dummy and date the crisis period as the interval between January 2008 and July 2009, which also overlaps with the US recession as indicated by the NBER. We rerun Eq. (4) based on the new crisis definition and find that our earlier results remain unchanged. As before, the sign switch effect occurs specifically in crisis-related news coefficients. It is evident in consumer price index (CPI), consumer confidence and federal funds rate releases. There is further evidence of sign changes in new home sales, retail sales, housing starts, initial claims and nonfarm payroll announcements for these currency markets (Table 6).

Among the specific announcement effects, the market reaction to employment reports (i.e. nonfarm payroll and initial claims) is striking. We find that positive employment news appreciates the dollar against the euro and pound in expansion, but depreciates it in recession (Table 6). Boyd et al. (2005) and Andersen et al. (2007) also find a similar sign switch in response to employment news in stock markets. Based on the standard asset-pricing model, they attribute this effect to 
Table 5

The changing effect of macroeconomic news during the financial crisis (August 1, 2007 and June 30, 2009). This table reports the contemporaneous US news surprise coefficients from the mean model in Eq. (4). For each currency pair, we run a pooled regression. The first column presents the coefficient of the news surprise variable interacted with the crisis indicator and the third column reports the coefficient of the news surprise variable interacted with the no-crisis dummy. The second and fourth columns provide the p-values of the respective coefficient estimates. The highlighted rows represent the coefficient equality tests that are statistically significant at the five percent level. The crisis period spans the interval between August 1, 2007 and June 30,2009 (as in Melvin and Taylor, 2009). The last row represents the coefficient estimates for the unscheduled news indicator.

\begin{tabular}{|c|c|c|c|c|c|c|c|c|c|c|c|c|}
\hline \multirow[b]{2}{*}{ News variables } & \multicolumn{4}{|l|}{ USD/EUR } & \multicolumn{4}{|l|}{ USD/GBP } & \multicolumn{4}{|l|}{ USD/JPY } \\
\hline & No-crisis & $p$-val & Crisis & $p$-val & No-crisis & $p$-val & Crisis & $p$-val & No-crisis & $p$-val & Crisis & $p$-val \\
\hline Capacity utilization & -0.006 & 0.473 & 0.028 & 0.104 & 0.004 & 0.672 & 0.089 & 0.000 & -0.016 & 0.100 & 0.003 & 0.886 \\
\hline GDP advanced report & -0.269 & 0.000 & -0.027 & 0.001 & -0.221 & 0.000 & -0.022 & 0.023 & -0.319 & 0.000 & 0.001 & 0.858 \\
\hline GDP second report & -0.018 & 0.045 & -0.052 & 0.000 & -0.011 & 0.284 & -0.007 & 0.470 & -0.053 & 0.000 & -0.065 & 0.000 \\
\hline GDP third report & 0.004 & 0.704 & -0.077 & 0.000 & 0.015 & 0.159 & -0.018 & 0.286 & -0.060 & 0.000 & -0.062 & 0.000 \\
\hline Industrial production & -0.003 & 0.727 & -0.017 & 0.327 & -0.011 & 0.247 & -0.068 & 0.000 & -0.012 & 0.174 & -0.019 & 0.295 \\
\hline Personal income & -0.002 & 0.769 & 0.019 & 0.059 & -0.006 & 0.380 & 0.041 & 0.000 & 0.006 & 0.347 & -0.022 & 0.031 \\
\hline Retail sales & -0.046 & 0.000 & 0.024 & 0.000 & -0.045 & 0.000 & 0.059 & 0.000 & -0.112 & 0.000 & -0.083 & 0.000 \\
\hline New home sales & -0.045 & 0.000 & 0.069 & 0.000 & -0.031 & 0.000 & 0.038 & 0.031 & -0.067 & 0.000 & -0.049 & 0.002 \\
\hline Personal expenditure & 0.013 & 0.009 & 0.016 & 0.047 & 0.010 & 0.065 & 0.019 & 0.021 & -0.009 & 0.100 & 0.005 & 0.573 \\
\hline Business inventories & 0.002 & 0.738 & -0.030 & 0.000 & 0.001 & 0.802 & -0.029 & 0.000 & -0.014 & 0.011 & 0.026 & 0.000 \\
\hline Construction spending & 0.013 & 0.003 & 0.022 & 0.000 & 0.003 & 0.562 & 0.016 & 0.006 & -0.016 & 0.001 & -0.026 & 0.000 \\
\hline Durable orders & -0.031 & 0.000 & 0.001 & 0.913 & -0.023 & 0.000 & -0.005 & 0.589 & -0.040 & 0.000 & -0.052 & 0.000 \\
\hline Factory orders & -0.017 & 0.001 & -0.027 & 0.000 & -0.017 & 0.004 & -0.012 & 0.045 & -0.027 & 0.000 & -0.040 & 0.000 \\
\hline CPI & -0.001 & 0.916 & 0.017 & 0.010 & -0.010 & 0.096 & 0.048 & 0.000 & -0.039 & 0.000 & 0.025 & 0.000 \\
\hline PPI & -0.024 & 0.000 & -0.028 & 0.001 & -0.018 & 0.005 & -0.052 & 0.000 & -0.040 & 0.000 & -0.035 & 0.000 \\
\hline Consumer confidence & -0.003 & 0.562 & 0.043 & 0.000 & -0.004 & 0.487 & 0.025 & 0.000 & -0.049 & 0.000 & 0.045 & 0.000 \\
\hline Housing starts & -0.018 & 0.001 & 0.049 & 0.000 & -0.013 & 0.035 & 0.045 & 0.000 & -0.040 & 0.000 & -0.036 & 0.001 \\
\hline ISM & -0.027 & 0.000 & -0.024 & 0.001 & -0.018 & 0.000 & -0.007 & 0.355 & -0.098 & 0.000 & -0.062 & 0.000 \\
\hline Leading indicators & -0.008 & 0.062 & 0.020 & 0.004 & -0.009 & 0.099 & 0.030 & 0.000 & -0.017 & 0.001 & -0.051 & 0.000 \\
\hline Initial claims & 0.008 & 0.001 & -0.023 & 0.000 & 0.011 & 0.000 & -0.029 & 0.000 & 0.056 & 0.000 & 0.000 & 0.902 \\
\hline Nonfarm payrolls & -0.107 & 0.000 & 0.048 & 0.000 & -0.104 & 0.000 & 0.035 & 0.000 & -0.255 & 0.000 & -0.122 & 0.000 \\
\hline Fed funds rate & -0.019 & 0.001 & -0.080 & 0.000 & -0.028 & 0.000 & -0.043 & 0.000 & -0.029 & 0.000 & 0.007 & 0.350 \\
\hline Trade balance & -0.095 & 0.000 & -0.018 & 0.003 & -0.073 & 0.000 & -0.010 & 0.104 & -0.085 & 0.000 & -0.043 & 0.000 \\
\hline \multirow[t]{2}{*}{ Treasury budget } & -0.006 & 0.477 & 0.013 & 0.028 & -0.008 & 0.440 & 0.000 & 0.960 & -0.005 & 0.570 & 0.012 & 0.030 \\
\hline & $\Omega$ total & & $p$-val & & $\Omega$ total & & $p$-val & & $\Omega$ total & & $p$-val & \\
\hline Unscheduled news & -0.004 & & 0.000 & & -0.000 & & 0.436 & & 0.000 & & 0.274 & \\
\hline
\end{tabular}

two competing influences on stock prices: Discount vs. cash flow effects. They argue that while cash flow effects are more prominent during contractions, discount rate effects dominate during expansions. This implies, in response to negative growth news, stock prices decrease during contractions and increase during expansions since negative growth news in expansions raise the likelihood of the central bank to lower interest rates to stimulate the economy. Although the news coefficient sign reversal we document in exchange rates is similar to the one illustrated by Boyd et al. (2005) and Andersen et al. (2007) in equity markets, the underlying models that generate this asymmetry are distinct given the differences in the nature of these two asset classes.

Most importantly, we find that the news coefficient sign reversal is most evident in reaction to retail sales, consumer confidence, consumer price index (CPI), new home sales, housing starts, non-farm payrolls and initial claims reports, which are the earliest releases within a month containing information about consumption, real-estate and labor markets (Table 6). Typically, the incremental information value of later releases within an indicator category is smaller compared to news releases that are announced earlier in a given month since later releases tend to contain data that have already been revealed to the public in the earlier releases of the related macro indicators (Cheung and Chinn, 2001; Andersen et al., 2003). For instance, among the 24 announcements that we study here, there are five announcements that contain information about real economic activity: GDP releases, capacity utilization, industrial production, personal income and retail sales. Within the real activity indicator category, retail sales is released the earliest in a given month and portrays strong sign asymmetry in euro and pound markets (Table 7). Similarly, consumer confidence is the first forward-looking variable released within a given month that portrays news effect sign asymmetry. Housing starts is another forward-looking variable and although it is not the earliest release within a month, due to the incremental information it contains about the state of the housing sector, it portrays significant sign asymmetry over our sample period.

Overall, our findings indicate the context-specific nature of the change in investors' reaction to news and reveal that announcement chronology within an indicator category matters for the sign switch effect to take place. The documented sign reversal in news reaction is context-specific because, in a given month, those announcements that are the earliest releases within an indicator category, which contain incremental information about consumption, real-estate and labor markets reveal sign asymmetry. Considering the significance of these markets in the evolution of the 2008-2009 financial crisis, investors rationally paid more attention to the signals in the earliest, most informative releases related to consumption, housing, credit and employment. 

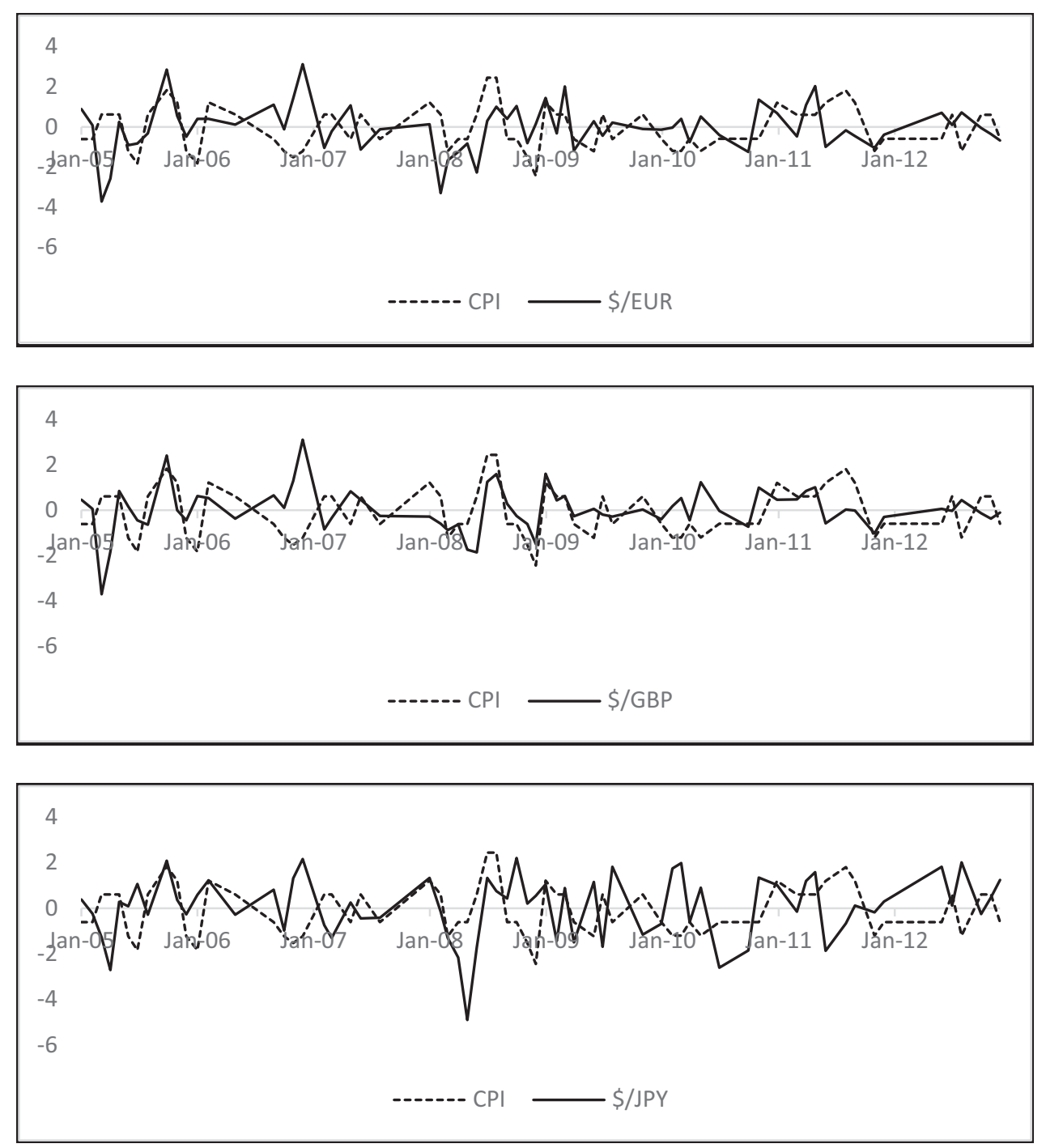

Fig. 1. US consumer price index. This figure plots the evolution of the surprise component of the CPI news releases along with the intraday returns of the three major currency pairs.

To our knowledge, we provide the first intraday evidence and analysis of the sign switch effect in the foreign exchange literature. The sign asymmetry we document is similar to that of Fratzscher (2009), which explores the cross-sectional determinants of the sharp depreciation of 54 currencies vis-à-vis the US dollar during the global financial crisis. Yet, based on daily return data, Fratzscher (2009) finds that almost of all of the important US news coefficients switched sign between July 2008 and January 2009. Contrary to these results, however, we show that only a selective few, crisis-related announcements' coefficients reversed sign during the financial turmoil. The difference in our findings largely stems from the window over which we calculate the exchange rate returns.

We believe that the intraday setting is particularly well-suited to examine the unusual behavior of exchange rates during this period because high-frequency data allow us to capture the direct link between currency movements and macro news where the 5-min window is tight enough to disentangle announcement-specific effects from other confounding factors such as unscheduled news releases by the Treasury, central banks and other regulatory institutions as well as unanticipated market events (e.g. capital injections by the Treasury, Lehman bankruptcy), which we incorporate in our analysis.

As a robustness check, we also redefine our crisis period to match the crisis interval (July 2008-January 2009) in Fratzscher (2009). Analyzing the same interval using intraday data, we find that there are even fewer sign switches in the three major currency markets during this period (Table 8 ). Our result contradicts the finding based on daily return analysis (in Fratzscher, 2009), which suggests that almost all major news coefficients reversed sign between July 2008 and January 2009. We believe that six months is too short time frame to study the sign switch effect as the number of observations in 

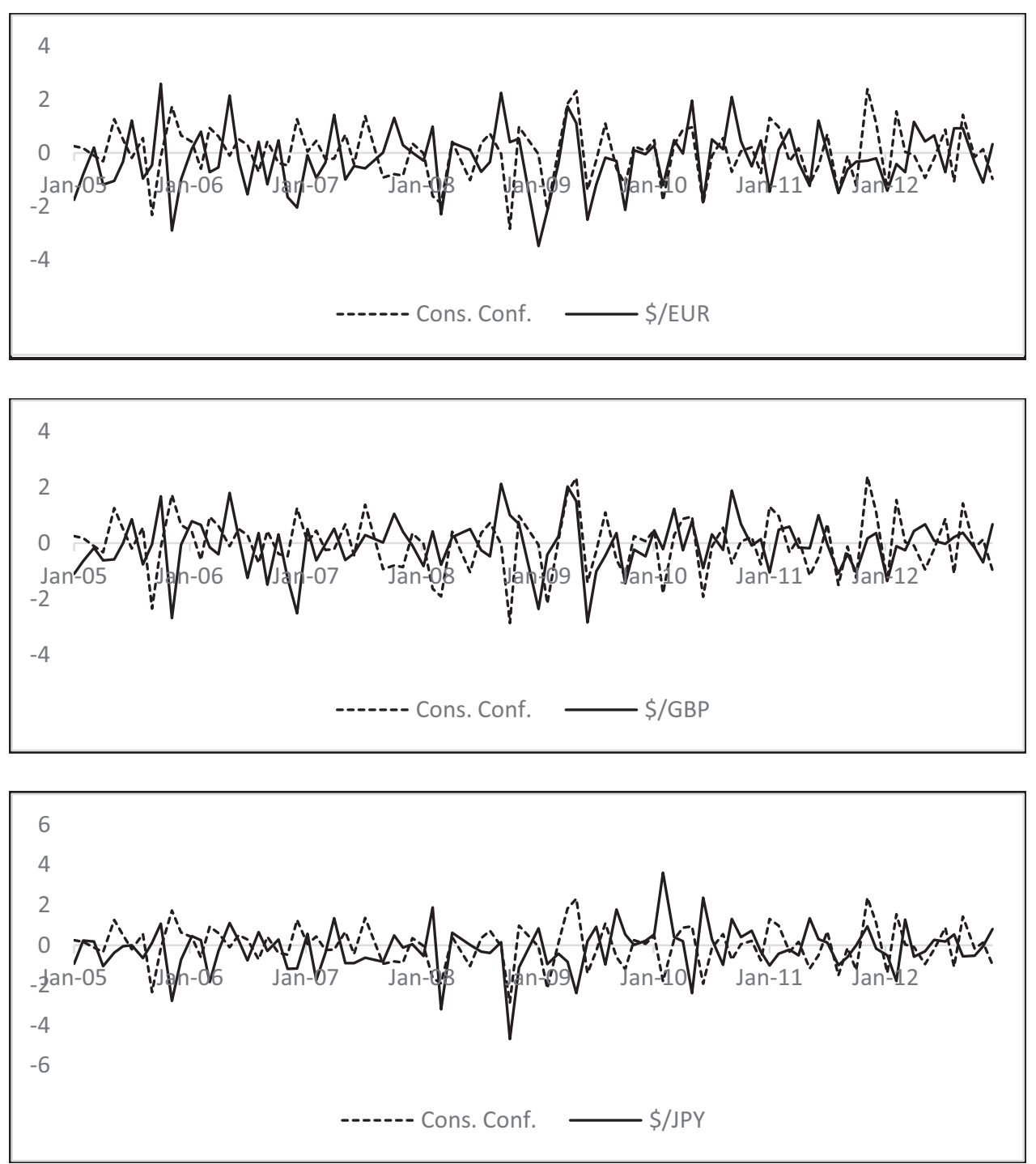

Fig. 2. US consumer confidence. This figure 2 plots the evolution of the surprise component of the US consumer confidence news releases along with the intraday returns of the three major currency pairs.

terms of monthly announcements per indicator is very limited. As our analysis clearly shows the sign switch effect has started earlier, i.e. in January 2008 and continued well into mid-2009.

Additionally, we test the persistence of our results over time and investigate whether the sign switch effect we document is reversed in later periods on a given announcement day. Reassuringly, the estimated coefficients of the lagged news surprise variables in Eq. (4) are insignificant, which suggests that the sign switch effect is not reversed in subsequent intervals (Table 9). ${ }^{7}$

\section{Determinants of the sign switch effect}

To explore possible causes of the change in news coefficient signs between 2005 and 2012, we consider two explanations suggested by the literature: (1) The safe-haven effect generated by an increase in the aggregate risk level, (2) the Fed's zero interest rate policy. There are several ways in which risk can affect the exchange-rate reaction to news. The first one involves the fluctuations in the risk premium associated with holding non-US dollar currency assets (Faust et al., 2007) and investors turning to safe, low-return US dollar denominated assets in response to the sharp increase in economic uncertainty (McCauley and McGuire, 2009; Gourinchas et al., 2010). The investors' flight to quality due to an increase in risk aversion

\footnotetext{
${ }^{7}$ We report the second lag of the US news response coefficients here.
} 

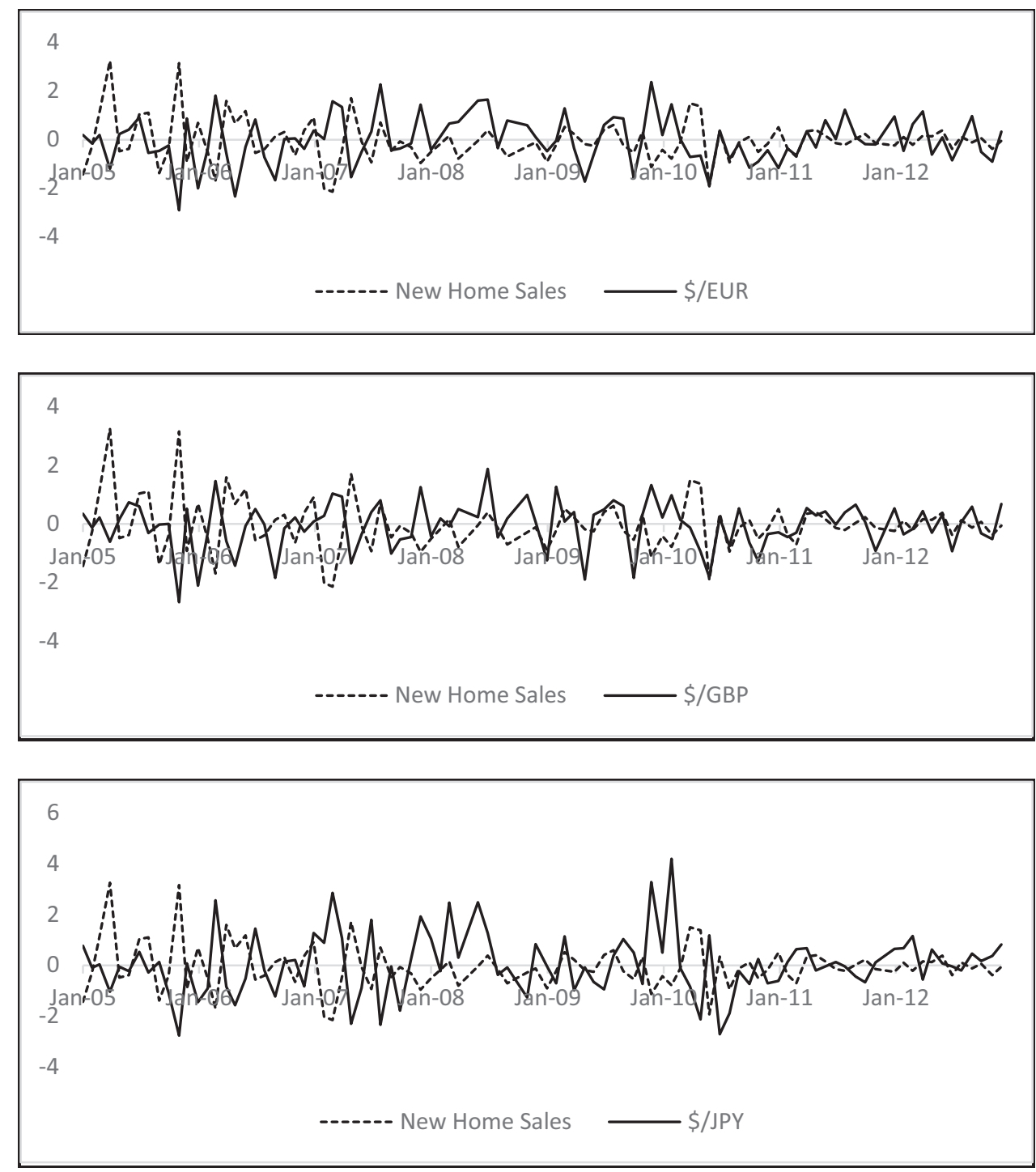

Fig. 3. US new home sales. This figure 3 plots the evolution of the surprise component of the US new home sales releases along with the intraday returns of the three major currency pairs.

is likely to result in a perverse relationship between macronews and exchange rates in that bad (good) US growth news signal even worse (better) global growth prospects, which impact other countries' currencies more negatively (positively) than the US dollar, and hence appreciate (depreciate) the dollar. Related to the changes in the risk premium, De Bock and De Carvalho, 2013 also highlight the role of unwinding of carry trade positions and show that exchange rates that are more sensitive to carry trade flows before the crisis tend to depreciate more against the US dollar during the financial crisis. As an alternative channel, Goldberg and Grisse (2013) point out that sharp fluctuations in risk conditions can shift the central bank priorities leading to a change in the investors' perception of future monetary policy, which can ultimately alter the reaction of bond and currency markets to macroeconomic news. Additionally, monetary policy can work through the risk-taking channel and these policy shocks themselves can have a significant impact on risk aversion (Bekaert et al., 2012; Bruno and Shin, 2013).

Through interest parity condition and Taylor-rule type monetary policy reaction functions, actual changes in central bank's interest rate policies as well as investors' updated expectations regarding future interest rate paths can influence how exchange rates react to macronews (Gürkaynak et al., 2005; Swanson and Williams, 2013, 2014; Goldberg and Grisse, 2013). For instance, as interest rates get closer to the zero bound, monetary policy could presumably become less effective. In such an environment, most of the adjustment would be reflected in future long-term interest rates and prices. Indeed when the Fed lowered the short term interest rates to zero in order to combat the recessionary effects of the financial crisis, markets began to pay less attention to short-term yields, rendering the long-term rates the effective tool for monetary 
Table 6

The changing effect of macroeconomic news: Alternative crisis definition (NBER recession dates: January 1, 2008 and June 30, 2009). This table reports the contemporaneous US news response coefficients from Eq. (4). For each currency pair, we run a pooled regression. The first (third) column presents the news surprise coefficients interacted with the crisis dummy (no-crisis dummy). The highlighted rows represent the coefficient equality tests that are statistically significant at the five percent level. Following the NBER, we define the crisis period as the interval between January 1, 2008 and June $30,2009$.

\begin{tabular}{|c|c|c|c|c|c|c|c|c|c|c|c|c|}
\hline \multirow[b]{2}{*}{ News variables } & \multicolumn{4}{|l|}{ USD/EUR } & \multicolumn{4}{|l|}{ USD/GBP } & \multicolumn{4}{|l|}{ USD/JPY } \\
\hline & No-crisis & $p$-val & Crisis & $p$-val & No-crisis & $p$-val & Crisis & $p$-val & No-crisis & $p$-val & Crisis & $p$-val \\
\hline Capacity utilization & -0.004 & 0.628 & 0.016 & 0.383 & -0.004 & 0.653 & 0.090 & 0.000 & -0.015 & 0.124 & -0.005 & 0.797 \\
\hline GDP advanced report & -0.269 & 0.000 & -0.026 & 0.001 & -0.065 & 0.000 & -0.022 & 0.024 & -0.319 & 0.000 & 0.002 & 0.767 \\
\hline GDP second report & -0.019 & 0.032 & -0.049 & 0.000 & 0.008 & 0.390 & -0.005 & 0.598 & -0.047 & 0.000 & -0.073 & 0.000 \\
\hline GDP third report & 0.004 & 0.694 & -0.077 & 0.000 & -0.030 & 0.004 & -0.018 & 0.283 & -0.057 & 0.000 & -0.062 & 0.000 \\
\hline Industrial production & -0.005 & 0.514 & -0.004 & 0.823 & 0.002 & 0.834 & -0.068 & 0.001 & -0.015 & 0.102 & -0.011 & 0.602 \\
\hline Personal income & -0.001 & 0.813 & 0.007 & 0.518 & 0.005 & 0.437 & 0.034 & 0.004 & 0.006 & 0.347 & -0.025 & 0.019 \\
\hline Retail sales & -0.047 & 0.000 & 0.024 & 0.000 & -0.010 & 0.049 & 0.059 & 0.000 & -0.115 & 0.000 & -0.078 & 0.000 \\
\hline New home sales & -0.043 & 0.000 & 0.069 & 0.000 & -0.012 & 0.025 & 0.052 & 0.010 & -0.071 & 0.000 & 0.068 & 0.001 \\
\hline Personal expenditure & 0.010 & 0.031 & 0.049 & 0.000 & 0.000 & 0.922 & 0.040 & 0.002 & -0.008 & 0.113 & 0.016 & 0.244 \\
\hline Business inventories & 0.001 & 0.874 & -0.030 & 0.000 & 0.002 & 0.654 & -0.032 & 0.000 & -0.014 & 0.010 & 0.029 & 0.000 \\
\hline Construction spending & 0.013 & 0.002 & 0.020 & 0.001 & 0.003 & 0.443 & 0.014 & 0.013 & -0.016 & 0.001 & -0.026 & 0.000 \\
\hline Durable orders & -0.031 & 0.000 & 0.015 & 0.067 & -0.001 & 0.830 & 0.002 & 0.870 & -0.051 & 0.000 & 0.004 & 0.695 \\
\hline Factory orders & -0.020 & 0.000 & -0.024 & 0.000 & -0.004 & 0.494 & -0.009 & 0.139 & -0.025 & 0.000 & -0.045 & 0.000 \\
\hline Consumer price index & -0.001 & 0.909 & 0.017 & 0.012 & 0.009 & 0.141 & 0.048 & 0.000 & -0.039 & 0.000 & 0.025 & 0.000 \\
\hline Producer price index & -0.025 & 0.000 & -0.016 & 0.108 & -0.009 & 0.124 & -0.045 & 0.000 & -0.033 & 0.000 & -0.042 & 0.000 \\
\hline Consumer confidence & -0.005 & 0.327 & 0.046 & 0.000 & -0.012 & 0.028 & 0.029 & 0.000 & -0.045 & 0.000 & 0.047 & 0.000 \\
\hline Housing starts & -0.018 & 0.001 & 0.051 & 0.000 & -0.011 & 0.072 & 0.046 & 0.000 & -0.040 & 0.000 & -0.037 & 0.001 \\
\hline ISM & -0.027 & 0.000 & -0.023 & 0.002 & -0.014 & 0.001 & -0.005 & 0.497 & -0.099 & 0.000 & -0.060 & 0.000 \\
\hline Leading indicators & -0.008 & 0.063 & 0.024 & 0.001 & -0.007 & 0.155 & 0.030 & 0.000 & -0.017 & 0.001 & -0.055 & 0.000 \\
\hline Initial claims & 0.009 & 0.000 & -0.026 & 0.000 & 0.002 & 0.487 & -0.030 & 0.000 & 0.055 & 0.000 & -0.001 & 0.805 \\
\hline Nonfarm payrolls & -0.119 & 0.000 & 0.098 & 0.000 & -0.013 & 0.000 & 0.072 & 0.000 & -0.269 & 0.000 & -0.055 & 0.000 \\
\hline Fed funds rate & -0.055 & 0.000 & 0.041 & 0.000 & 0.031 & 0.000 & 0.008 & 0.429 & -0.026 & 0.000 & 0.017 & 0.076 \\
\hline Trade balance & -0.095 & 0.000 & -0.017 & 0.006 & 0.000 & 0.930 & -0.008 & 0.189 & -0.084 & 0.000 & -0.044 & 0.000 \\
\hline \multirow[t]{2}{*}{ Treasury budget } & -0.006 & 0.443 & 0.014 & 0.022 & -0.008 & 0.386 & 0.000 & 0.936 & -0.004 & 0.621 & 0.012 & 0.028 \\
\hline & $\Omega$ Total & & $p$-val & & $\Omega$ Total & & $p$-val & & $\Omega$ Total & & $p$-val & \\
\hline Unscheduled News & 0.000 & & 0.466 & & -0.000 & & 0.437 & & 0.000 & & 0.265 & \\
\hline
\end{tabular}

policy (Swanson and Williams, 2013, 2014). In such a setting, investors' interpretation of what a given macroeconomic announcement implies for future monetary policy could be different than when the short term interest rates are not constrained by the zero bound and through interest parity condition, this could affect the sensitivity of exchange rates to macroeconomic announcements.

To account for these possibilities, we augment the conditional mean model by interacting our measures of risk, carry trade returns and interest rates with the news surprise variable (Eq. (6)). As explained in the data section, we use the implied volatility of the S\&P 500 index options, $\left(\mathrm{VIX}_{\mathrm{t}}\right)$, as a proxy for risk, which is the standard risk measure in the literature (Goldberg and Grisse, 2013; De Bock and De Carvalho, 2013). To capture the effect of the Fed's interest rate policies over our sample period, we use the 10-year real treasury yields $\left(\mathrm{LTR}_{\mathrm{t}}\right)$ as the relevant measure of monetary policy. We include the 5-min Australian dollar-Japanese yen exchange rates $\left(A U D_{t}\right)$ in our augmented model to measure the effect of the changes in the profitability and the direction of the carry trade flows given the popularity of this currency pair among the G-10 carry trade investors (De Bock and De Carvalho, 2013).

Augmented model results suggest that the average reaction of the US dollar to US macroeconomic news is in line with the predictions of the standard models of exchange rate determination. That is, when the values of VIX, AUD $_{t}$ and LTR $_{t}$ are at their respective sample averages, ${ }^{8}$ the US dollar appreciates (depreciates) vis-à-vis the three major currency pairs in response to a given positive (negative) US news surprise (Tables 10A, 10B, 10C). As an example, consider the non-farm payroll announcement. During normal times when $\mathrm{VIX}_{\mathrm{t}}, \mathrm{AUD}_{\mathrm{t}}$ and $\mathrm{LTR}_{\mathrm{t}}$ are at their sample means, a one standard deviation positive US payroll employment surprise, as expected, appreciates the dollar by about 8 basis points against the euro. However, a one standard deviation increase in risk, VIX , dampens the appreciation of the dollar in response to a positive surprise by 5 basis points (Table 10A). Similarly, the coefficient signs of new home sales, retail sales, construction spending, housing starts and initial claims announcements are also sensitive to fluctuations in the risk level. About half of the announcements whose coefficients switch sign in the euro-dollar and pound-dollar markets in Tables 5 and 6 have positive news surprise interaction coefficients with the VIX variable in Tables 10A and 10B. Overall, our results suggest that the appreciation of the dollar in response to good US news dampens as the general risk level increases.

\footnotetext{
${ }^{8}$ We center and standardize these variables around their respective sample means. For instance, when VIX $\mathrm{t}_{\mathrm{t}}$ is equal to zero, the volatility index is at its sample average.
} 


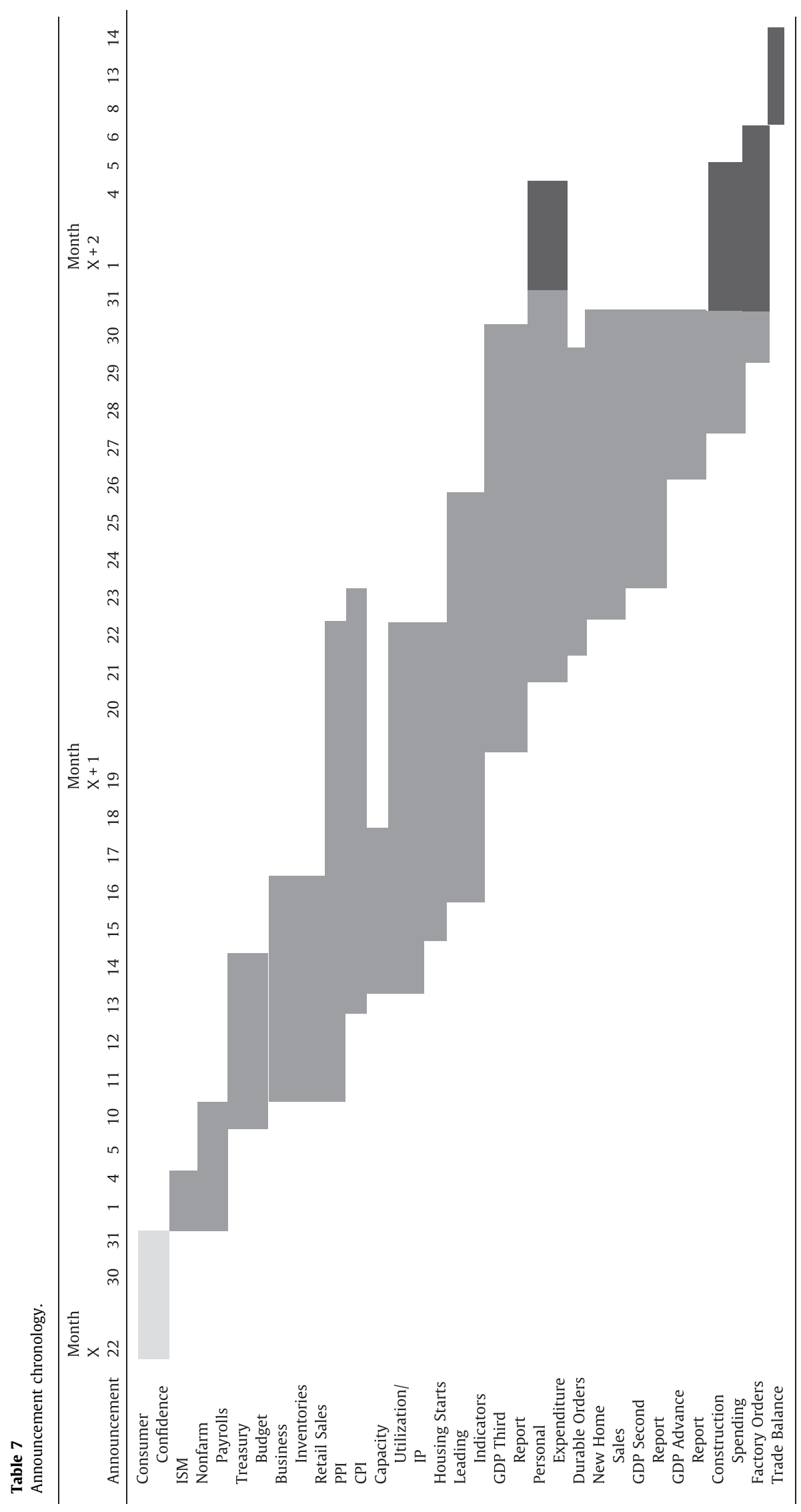


Table 8

The changing effect of macroeconomic news: Alternative crisis definition in Fratzscher (2009) (July 1, 2008 and January 31, 2009). This table reports the contemporaneous US news response coefficients from the mean model in Eq. (4). For each currency pair, we run a pooled regression. The first (third) column presents the news surprise coefficients interacted with the crisis dummy (no-crisis dummy). The crisis episode is defined to match that of Fratzscher (2009) and spans the interval July 1, 2008 - January 31, 2009. The highlighted rows represent statistically significant coefficient equality tests at the five percent level.

\begin{tabular}{|c|c|c|c|c|c|c|c|c|c|c|c|c|}
\hline \multirow[b]{2}{*}{ News variables } & \multicolumn{4}{|l|}{ USD/EUR } & \multicolumn{4}{|l|}{ USD/GBP } & \multicolumn{4}{|l|}{ USD/JPY } \\
\hline & No-crisis & $p$-val & Crisis & $p$-val & No-crisis & $p$-val & Crisis & $p$-val & No-crisis & $p$-val & Crisis & $p$-val \\
\hline Capacity utilization & 0.001 & 0.925 & 0.068 & 0.219 & 0.027 & 0.002 & 0.063 & 0.314 & -0.018 & 0.042 & 0.083 & 0.180 \\
\hline GDP advanced report & -0.040 & 0.000 & -0.108 & 0.019 & -0.037 & 0.000 & -0.008 & 0.900 & -0.019 & 0.002 & -0.212 & 0.000 \\
\hline GDP second report & -0.025 & 0.001 & -0.150 & 0.000 & -0.003 & 0.658 & -0.100 & 0.017 & -0.058 & 0.000 & -0.079 & 0.009 \\
\hline GDP third report & -0.011 & 0.237 & -0.098 & 0.000 & 0.001 & 0.945 & 0.007 & 0.763 & -0.053 & 0.000 & -0.098 & 0.000 \\
\hline Industrial production & -0.006 & 0.446 & -0.055 & 0.282 & -0.022 & 0.013 & -0.047 & 0.418 & -0.019 & 0.024 & -0.081 & 0.147 \\
\hline Personal income & 0.002 & 0.664 & 0.186 & 0.000 & 0.007 & 0.208 & 0.184 & 0.000 & 0.001 & 0.823 & 0.073 & 0.103 \\
\hline Retail sales & -0.006 & 0.148 & -0.039 & 0.000 & 0.010 & 0.022 & -0.008 & 0.424 & -0.100 & 0.000 & -0.069 & 0.000 \\
\hline New home sales & -0.044 & 0.000 & 0.011 & 0.668 & -0.033 & 0.000 & 0.080 & 0.003 & -0.070 & 0.000 & 0.051 & 0.113 \\
\hline Personal expenditure & 0.012 & 0.005 & 0.270 & 0.000 & 0.011 & 0.014 & 0.263 & 0.000 & -0.010 & 0.027 & 0.107 & 0.007 \\
\hline Business inventories & -0.004 & 0.384 & -0.061 & 0.000 & -0.004 & 0.373 & -0.064 & 0.000 & -0.002 & 0.582 & 0.032 & 0.009 \\
\hline Construction spending & 0.017 & 0.000 & -0.057 & 0.132 & 0.009 & 0.020 & -0.085 & 0.024 & -0.019 & 0.000 & -0.201 & 0.000 \\
\hline Durable orders & -0.018 & 0.000 & -0.139 & 0.000 & -0.010 & 0.034 & -0.096 & 0.000 & -0.047 & 0.000 & 0.076 & 0.000 \\
\hline Factory orders & -0.023 & 0.000 & -0.018 & 0.008 & -0.024 & 0.000 & -0.002 & 0.815 & -0.028 & 0.000 & -0.048 & 0.000 \\
\hline Consumer price index & 0.007 & 0.176 & 0.025 & 0.001 & 0.000 & 0.999 & 0.059 & 0.000 & -0.024 & 0.000 & 0.016 & 0.031 \\
\hline Producer price index & -0.020 & 0.000 & -0.036 & 0.008 & -0.015 & 0.003 & -0.112 & 0.000 & -0.031 & 0.000 & -0.027 & 0.049 \\
\hline Consumer confidence & 0.024 & 0.000 & -0.006 & 0.569 & -0.018 & 0.000 & 0.025 & 0.013 & -0.031 & 0.000 & 0.136 & 0.000 \\
\hline Housing starts & -0.008 & 0.122 & -0.012 & 0.526 & -0.004 & 0.541 & 0.013 & 0.530 & -0.038 & 0.000 & -0.035 & 0.075 \\
\hline ISM & -0.019 & 0.000 & -0.075 & 0.000 & -0.008 & 0.085 & -0.069 & 0.000 & -0.102 & 0.000 & -0.074 & 0.000 \\
\hline Leading indicators & -0.010 & 0.014 & 0.050 & 0.000 & -0.009 & 0.057 & 0.059 & 0.000 & -0.020 & 0.000 & -0.069 & 0.000 \\
\hline Initial claims & 0.006 & 0.005 & -0.048 & 0.000 & 0.006 & 0.011 & -0.045 & 0.000 & 0.051 & 0.000 & -0.025 & 0.000 \\
\hline Nonfarm payrolls & -0.054 & 0.000 & 0.017 & 0.077 & -0.053 & 0.000 & -0.004 & 0.658 & -0.244 & 0.000 & 0.055 & 0.000 \\
\hline Fed funds rate & -0.037 & 0.000 & 0.006 & 0.685 & -0.035 & 0.000 & -0.015 & 0.257 & -0.017 & 0.001 & 0.007 & 0.639 \\
\hline Trade balance & -0.070 & 0.000 & -0.011 & 0.190 & -0.054 & 0.000 & -0.009 & 0.291 & -0.064 & 0.000 & -0.065 & 0.000 \\
\hline Treasury budget & -0.005 & 0.534 & 0.015 & 0.019 & -0.007 & 0.423 & 0.001 & 0.892 & -0.003 & 0.656 & 0.013 & 0.020 \\
\hline
\end{tabular}

Table 9

Persistence of the sign switch effect: 10-min US news response coefficients from the mean model. This table reports the 10-min (2nd lag of) US news response coefficients estimates in Eq. (4). For each currency pair, we run a pooled regression where the first (third) column presents the news surprise coefficients interacted with the crisis dummy (no-crisis dummy). The crisis is defined as the interval between August 1, 2007 and June 30, 2009.

\begin{tabular}{|c|c|c|c|c|c|c|c|c|c|c|c|c|}
\hline \multirow[b]{2}{*}{ News variables } & \multicolumn{4}{|l|}{ USD/EUR } & \multicolumn{4}{|l|}{ USD/GBP } & \multicolumn{4}{|l|}{ USD/JPY } \\
\hline & No-crisis & $p$-val & Crisis & $p$-val & No-crisis & $p$-val & Crisis & $p$-val & No-crisis & $p$-val & Crisis & $p$-val \\
\hline Capacity utilization & 0.005 & 0.557 & -0.066 & 0.000 & 0.003 & 0.776 & -0.065 & 0.001 & 0.007 & 0.481 & -0.003 & 0.869 \\
\hline GDP advanced report & -0.006 & 0.661 & -0.006 & 0.421 & -0.034 & 0.061 & -0.001 & 0.893 & -0.048 & 0.006 & 0.002 & 0.791 \\
\hline GDP second report & 0.023 & 0.006 & -0.003 & 0.764 & 0.017 & 0.084 & -0.016 & 0.132 & -0.004 & 0.698 & 0.084 & 0.000 \\
\hline GDP third report & 0.003 & 0.778 & 0.013 & 0.378 & 0.000 & 0.967 & 0.005 & 0.745 & -0.002 & 0.858 & 0.000 & 0.993 \\
\hline Industrial production & -0.007 & 0.353 & 0.091 & 0.000 & -0.009 & 0.326 & 0.087 & 0.000 & 0.002 & 0.797 & 0.008 & 0.705 \\
\hline Personal income & 0.003 & 0.556 & -0.040 & 0.000 & -0.001 & 0.892 & -0.041 & 0.000 & 0.001 & 0.936 & -0.023 & 0.037 \\
\hline Retail sales & -0.009 & 0.049 & -0.003 & 0.585 & -0.001 & 0.823 & 0.027 & 0.000 & -0.016 & 0.002 & -0.006 & 0.305 \\
\hline New home sales & 0.002 & 0.711 & -0.034 & 0.148 & 0.002 & 0.737 & 0.036 & 0.080 & 0.009 & 0.045 & -0.075 & 0.144 \\
\hline Personal expenditure & -0.004 & 0.409 & 0.067 & 0.000 & -0.003 & 0.605 & 0.062 & 0.000 & 0.003 & 0.512 & 0.002 & 0.874 \\
\hline Business inventories & 0.013 & 0.007 & -0.007 & 0.268 & 0.016 & 0.003 & 0.005 & 0.456 & 0.008 & 0.140 & -0.010 & 0.127 \\
\hline Construction spending & 0.008 & 0.028 & 0.032 & 0.000 & 0.007 & 0.107 & 0.046 & 0.000 & 0.003 & 0.543 & -0.008 & 0.222 \\
\hline Durable orders & -0.007 & 0.142 & -0.028 & 0.247 & -0.005 & 0.311 & -0.046 & 0.000 & -0.004 & 0.412 & -0.006 & 0.510 \\
\hline Factory orders & -0.007 & 0.157 & 0.006 & 0.357 & -0.001 & 0.821 & -0.014 & 0.021 & 0.006 & 0.296 & -0.001 & 0.891 \\
\hline Consumer price index & 0.000 & 0.935 & -0.006 & 0.364 & 0.005 & 0.411 & -0.011 & 0.137 & 0.018 & 0.002 & 0.034 & 0.000 \\
\hline Producer price index & 0.012 & 0.017 & 0.045 & 0.000 & 0.015 & 0.009 & 0.032 & 0.002 & 0.006 & 0.227 & -0.011 & 0.222 \\
\hline Consumer confidence & 0.003 & 0.512 & 0.008 & 0.154 & -0.001 & 0.825 & 0.029 & 0.000 & 0.007 & 0.167 & 0.000 & 0.970 \\
\hline Housing starts & 0.008 & 0.121 & 0.003 & 0.805 & 0.013 & 0.034 & -0.025 & 0.052 & 0.004 & 0.545 & 0.026 & 0.021 \\
\hline ISM & -0.008 & 0.050 & -0.001 & 0.869 & -0.004 & 0.373 & 0.013 & 0.085 & -0.022 & 0.000 & 0.033 & 0.000 \\
\hline Leading indicators & -0.003 & 0.457 & 0.013 & 0.077 & 0.006 & 0.211 & -0.013 & 0.098 & -0.012 & 0.006 & 0.017 & 0.022 \\
\hline Initial claims & 0.005 & 0.020 & 0.003 & 0.312 & 0.003 & 0.247 & 0.002 & 0.483 & 0.005 & 0.078 & 0.005 & 0.117 \\
\hline Nonfarm payrolls & -0.009 & 0.003 & -0.033 & 0.154 & -0.024 & 0.000 & 0.010 & 0.112 & -0.044 & 0.000 & -0.016 & 0.010 \\
\hline Fed funds rate & -0.034 & 0.000 & 0.010 & 0.268 & -0.019 & 0.008 & 0.019 & 0.058 & -0.044 & 0.000 & 0.000 & 0.996 \\
\hline Trade balance & -0.009 & 0.021 & -0.020 & 0.002 & -0.005 & 0.279 & 0.015 & 0.016 & 0.008 & 0.114 & 0.021 & 0.003 \\
\hline Treasury budget & -0.014 & 0.084 & 0.023 & 0.000 & -0.005 & 0.563 & 0.022 & 0.000 & 0.001 & 0.895 & 0.004 & 0.487 \\
\hline
\end{tabular}


Table 10A

Contemporaneous US news response coefficients from the augmented model: USD/EUR. This table reports the contemporaneous US news response coefficients from the augmented model in Eq. (6), which includes interactions of the implied volatility of the S\&P 500 index options (VIX), the 10-year treasury rates (LTR) and the 5-min Australian dollar-Japanese yen exchange rate (AUD) with the news surprise variables. We center and standardize the three variables around their respective sample means and use the standardized versions in the estimation of Eq. (3).

\begin{tabular}{|c|c|c|c|c|c|c|c|c|}
\hline News variables & Surprise & $p$-val & Surprise $\times$ VIX & $p$-val & Surprise $\times$ AUD & $p$-val & Surprise $\times$ LTR & $p$-val \\
\hline Capacity utilization & -0.004 & 0.671 & -0.003 & 0.837 & 0.001 & 0.922 & -0.006 & 0.520 \\
\hline GDP advanced report & -0.213 & 0.000 & 0.121 & 0.000 & 0.021 & 0.453 & -0.204 & 0.000 \\
\hline GDP second report & -0.045 & 0.000 & -0.043 & 0.021 & -0.045 & 0.005 & -0.024 & 0.016 \\
\hline GDP third report & -0.029 & 0.003 & -0.041 & 0.001 & -0.028 & 0.094 & -0.014 & 0.278 \\
\hline Industrial production & -0.009 & 0.253 & -0.003 & 0.839 & -0.026 & 0.085 & -0.005 & 0.563 \\
\hline Personal income & 0.012 & 0.074 & 0.007 & 0.331 & -0.009 & 0.102 & -0.021 & 0.051 \\
\hline Retail sales & -0.038 & 0.000 & 0.026 & 0.000 & -0.002 & 0.718 & -0.024 & 0.000 \\
\hline New home sales & 0.000 & 0.982 & 0.031 & 0.001 & -0.002 & 0.796 & -0.037 & 0.001 \\
\hline Personal expenditure & 0.013 & 0.003 & -0.005 & 0.443 & -0.007 & 0.208 & 0.007 & 0.201 \\
\hline Business inventories & -0.003 & 0.531 & -0.014 & 0.014 & 0.002 & 0.724 & -0.016 & 0.008 \\
\hline Construction spending & 0.025 & 0.000 & 0.042 & 0.000 & 0.046 & 0.000 & 0.007 & 0.156 \\
\hline Durable orders & -0.023 & 0.000 & -0.003 & 0.609 & 0.001 & 0.923 & -0.021 & 0.000 \\
\hline Factory orders & -0.022 & 0.000 & -0.006 & 0.182 & -0.007 & 0.216 & -0.002 & 0.725 \\
\hline Consumer price index & 0.006 & 0.181 & 0.003 & 0.505 & 0.000 & 0.976 & -0.010 & 0.125 \\
\hline Producer price index & -0.012 & 0.024 & -0.003 & 0.549 & -0.005 & 0.381 & -0.020 & 0.004 \\
\hline Consumer confidence & 0.011 & 0.011 & -0.009 & 0.015 & -0.028 & 0.000 & -0.009 & 0.051 \\
\hline Housing starts & -0.002 & 0.780 & 0.012 & 0.104 & 0.006 & 0.504 & -0.008 & 0.328 \\
\hline ISM & -0.023 & 0.000 & 0.010 & 0.015 & -0.001 & 0.826 & -0.015 & 0.012 \\
\hline Leading indicators & -0.006 & 0.143 & -0.006 & 0.211 & -0.020 & 0.000 & 0.006 & 0.205 \\
\hline Initial claims & 0.003 & 0.198 & -0.005 & 0.019 & 0.011 & 0.000 & 0.021 & 0.000 \\
\hline Nonfarm payrolls & -0.076 & 0.000 & 0.050 & 0.000 & -0.018 & 0.000 & 0.011 & 0.022 \\
\hline Fed funds rate & -0.057 & 0.000 & 0.083 & 0.000 & -0.015 & 0.008 & -0.181 & 0.000 \\
\hline Trade balance & -0.063 & 0.000 & 0.060 & 0.000 & 0.060 & 0.000 & -0.068 & 0.000 \\
\hline \multirow[t]{2}{*}{ Treasury budget } & 0.001 & 0.870 & -0.003 & 0.639 & -0.009 & 0.323 & 0.008 & 0.348 \\
\hline & $\Omega$ total & $p$-val & & & & & & \\
\hline Unscheduled News & 0.000 & 0.310 & & & & & & \\
\hline
\end{tabular}

\section{Table 10B}

Contemporaneous US news response coefficients from the augmented model: USD/GBP. This table reports the contemporaneous US news response coefficients from the augmented model in Eq. (6), which includes interactions of the implied volatility of the S\&P 500 index options (VIX), the 10-year treasury rates (LTR) and the 5-min Australian dollar-Japanese yen exchange rate (AUD) with the news surprise variables. We center and standardize the three variables around their respective sample means and use the standardized versions in the estimation of Eq. (3).

\begin{tabular}{|c|c|c|c|c|c|c|c|c|}
\hline News variables & Surprise & $p$-val & Surprise $\times$ VIX & $p$-val & Surprise $\times$ AUD & $p$-val & Surprise $\times$ LTR & $p$-val \\
\hline Capacity utilization & 0.014 & 0.128 & 0.011 & 0.496 & -0.016 & 0.326 & -0.001 & 0.956 \\
\hline GDP advanced report & -0.184 & 0.000 & 0.145 & 0.000 & 0.058 & 0.078 & -0.196 & 0.000 \\
\hline GDP second report & -0.025 & 0.013 & -0.022 & 0.276 & -0.031 & 0.079 & -0.018 & 0.126 \\
\hline GDP third report & 0.004 & 0.664 & -0.006 & 0.684 & 0.013 & 0.466 & -0.005 & 0.737 \\
\hline Industrial production & -0.022 & 0.016 & -0.008 & 0.568 & 0.005 & 0.767 & -0.012 & 0.191 \\
\hline Personal income & 0.004 & 0.575 & 0.015 & 0.062 & -0.008 & 0.237 & 0.005 & 0.668 \\
\hline Retail sales & -0.030 & 0.000 & 0.044 & 0.000 & 0.004 & 0.569 & -0.012 & 0.092 \\
\hline New home sales & 0.010 & 0.211 & 0.012 & 0.261 & -0.006 & 0.434 & -0.052 & 0.000 \\
\hline Personal expenditure & 0.011 & 0.022 & 0.008 & 0.241 & -0.005 & 0.442 & 0.009 & 0.131 \\
\hline Business inventories & -0.003 & 0.602 & -0.017 & 0.006 & -0.001 & 0.829 & -0.011 & 0.124 \\
\hline Construction spending & 0.013 & 0.005 & 0.041 & 0.000 & 0.043 & 0.000 & 0.000 & 0.957 \\
\hline Durable orders & -0.014 & 0.008 & -0.005 & 0.361 & 0.001 & 0.918 & -0.020 & 0.002 \\
\hline Factory orders & -0.022 & 0.000 & 0.012 & 0.014 & 0.003 & 0.607 & 0.008 & 0.173 \\
\hline Consumer price index & 0.006 & 0.301 & 0.020 & 0.000 & 0.015 & 0.011 & -0.013 & 0.090 \\
\hline Producer price index & -0.003 & 0.617 & -0.021 & 0.000 & -0.005 & 0.409 & -0.037 & 0.000 \\
\hline Consumer confidence & -0.011 & 0.026 & 0.014 & 0.000 & -0.025 & 0.000 & -0.012 & 0.025 \\
\hline Housing starts & 0.000 & 0.953 & 0.011 & 0.176 & -0.005 & 0.565 & -0.005 & 0.623 \\
\hline ISM & -0.016 & 0.000 & 0.012 & 0.006 & -0.001 & 0.857 & -0.004 & 0.623 \\
\hline Leading indicators & -0.003 & 0.497 & 0.008 & 0.167 & -0.007 & 0.270 & 0.004 & 0.438 \\
\hline Initial claims & 0.003 & 0.152 & -0.011 & 0.000 & 0.006 & 0.040 & 0.020 & 0.000 \\
\hline Nonfarm payrolls & -0.066 & 0.000 & 0.021 & 0.000 & -0.027 & 0.000 & -0.030 & 0.000 \\
\hline Fed funds rate & -0.057 & 0.000 & 0.071 & 0.000 & 0.011 & 0.093 & -0.174 & 0.000 \\
\hline Trade balance & -0.051 & 0.000 & 0.044 & 0.000 & 0.042 & 0.000 & -0.051 & 0.000 \\
\hline \multirow[t]{2}{*}{ Treasury budget } & -0.002 & 0.847 & -0.002 & 0.790 & -0.003 & 0.805 & 0.008 & 0.449 \\
\hline & $\Omega$ total & $p$-val & & & & & & \\
\hline Unscheduled News & -0.000 & 0.437 & & & & & & \\
\hline
\end{tabular}


Table 10C

Contemporaneous US news response coefficients from the augmented model: USD/JPY. This table reports the contemporaneous US news response coefficients from the augmented model in Eq. (6), which includes interactions of the implied volatility of the S\&P 500 index options (VIX), the 10-year treasury rates (LTR) and the 5-min Australian dollar-Japanese yen exchange rate (AUD) with the news surprise variables. We center and standardize the three variables around their respective sample means and use the standardized versions in the estimation of Eq. (3).

\begin{tabular}{|c|c|c|c|c|c|c|c|c|}
\hline News variables & Surprise & $p$-val & Surprise $\times$ VIX & $p$-val & Surprise $\times$ AUD & $p$-val & Surprise $\times$ LTR & $p$-val \\
\hline Capacity utilization & -0.013 & 0.154 & 0.009 & 0.570 & 0.019 & 0.224 & -0.009 & 0.378 \\
\hline GDP advanced report & -0.286 & 0.000 & 0.112 & 0.001 & -0.066 & 0.030 & 0.000 & 0.996 \\
\hline GDP second report & -0.050 & 0.000 & 0.045 & 0.016 & 0.047 & 0.004 & 0.011 & 0.347 \\
\hline GDP third report & -0.065 & 0.000 & -0.021 & 0.100 & -0.042 & 0.014 & -0.004 & 0.760 \\
\hline Industrial production & -0.019 & 0.028 & -0.008 & 0.552 & -0.029 & 0.053 & 0.000 & 0.957 \\
\hline Personal income & -0.005 & 0.537 & -0.022 & 0.003 & -0.003 & 0.639 & -0.003 & 0.794 \\
\hline Retail sales & -0.105 & 0.000 & 0.008 & 0.145 & -0.004 & 0.454 & 0.004 & 0.612 \\
\hline New home sales & -0.056 & 0.000 & -0.028 & 0.003 & -0.030 & 0.000 & -0.023 & 0.070 \\
\hline Personal expenditure & -0.009 & 0.061 & 0.013 & 0.061 & 0.010 & 0.140 & 0.011 & 0.082 \\
\hline Business inventories & -0.006 & 0.231 & 0.018 & 0.002 & -0.001 & 0.790 & -0.005 & 0.473 \\
\hline Construction spending & -0.009 & 0.043 & -0.006 & 0.397 & 0.026 & 0.001 & -0.031 & 0.000 \\
\hline Durable orders & -0.044 & 0.000 & 0.003 & 0.553 & -0.033 & 0.000 & 0.007 & 0.261 \\
\hline Factory orders & -0.037 & 0.000 & -0.012 & 0.012 & -0.027 & 0.000 & 0.013 & 0.033 \\
\hline Consumer price index & -0.018 & 0.001 & 0.021 & 0.000 & 0.034 & 0.000 & -0.004 & 0.610 \\
\hline Producer price index & -0.037 & 0.000 & 0.000 & 0.927 & -0.013 & 0.016 & 0.018 & 0.021 \\
\hline Consumer confidence & -0.039 & 0.000 & 0.052 & 0.000 & 0.040 & 0.000 & -0.003 & 0.498 \\
\hline Housing starts & -0.037 & 0.000 & 0.052 & 0.000 & 0.028 & 0.000 & 0.046 & 0.000 \\
\hline ISM & -0.117 & 0.000 & -0.026 & 0.000 & -0.019 & 0.004 & 0.053 & 0.000 \\
\hline Leading indicators & -0.021 & 0.000 & 0.016 & 0.003 & 0.032 & 0.000 & -0.011 & 0.048 \\
\hline Initial claims & 0.038 & 0.000 & -0.015 & 0.000 & 0.001 & 0.569 & -0.004 & 0.176 \\
\hline Nonfarm payrolls & -0.274 & 0.000 & 0.013 & 0.000 & -0.108 & 0.000 & 0.048 & 0.000 \\
\hline Fed funds rate & -0.027 & 0.001 & -0.016 & 0.009 & 0.021 & 0.000 & -0.083 & 0.000 \\
\hline Trade balance & -0.059 & 0.000 & 0.050 & 0.000 & 0.064 & 0.000 & -0.053 & 0.000 \\
\hline \multirow[t]{2}{*}{ Treasury budget } & -0.005 & 0.555 & 0.008 & 0.268 & 0.006 & 0.531 & -0.003 & 0.743 \\
\hline & $\Omega$ total & $p$-val & & & & & & \\
\hline Unscheduled News & -0.001 & 0.837 & & & & & & \\
\hline
\end{tabular}

Turning to carry trade flows, we find that fluctuations in carry trade returns matter especially in the dollar-yen market. In particular, the US dollar appreciation in response to positive US growth in construction spending, housing starts, CPI and the target federal funds rate announcements dampens as the Australian dollar appreciates against the yen. Considering the Australian dollar depreciation against the yen as an indication of carry trade reversals, the latter finding implies that the dollar appreciation in response to positive growth news in these announcements is muted when carry trade is more profitable (Table 10C).

Regarding the Fed's monetary policy, we find that the long-term interest rates are an important contributor to the timevarying news effects in almost all announcement categories. In line with the standard models of exchange rate determination, our results show that increases in the 10-year real interest rates amplify the US dollar's appreciation vis-à-vis the three major currencies in response to positive US growth news surprises. Our finding indicates that an increase in long-term rates reinforce the positive effect of growth news on the US dollar, implying that although long-term rates exert a very strong influence on the news coefficients in the expected direction, they do not contribute to the change in the news coefficient sign. This result supports Swanson and Williams (2014), which suggest that the euro-dollar and pound-dollar reaction to macro news have largely been unaffected by the Fed's unconventional policies and the exchange rates' reaction to macroeconomic news did not change due to the zero lower bound.

Overall, our findings indicate that the sign switch effect we document over the 2005-2012 period is primarily driven by the changes in the market risk and carry trade returns. We confirm the flight-to-quality hypothesis documented in the literature (McCauley and McGuire, 2009; McGuire and von Peter, 2009; De Bock and De Carvalho, 2013; Goldberg and Grisse, 2013) and the analysis in Gourinchas et al. (2010), which suggests that, as the center of the international monetary system, the US acts like a global insurer. This means that during times of global distress, it has an "exorbitant duty" to make payments to the rest of the world (similar to insurance claims), which amounted to 19 percent of its GDP over the 20072009 period (Gourinchas et al., 2010). The risk-driven sign switch effect we document lends support to this analysis, in that, in times of global distress, investors everywhere become risk averse and demand safe US-dollar assets. When there are bad news emanating from the US, investors in the US and the rest of the world become more risk averse and increase their demand for safe assets, which appreciates the dollar. When there are good news emanating from the US, investors expectation about global growth prospects improve, which leads them to reduce their demand for US-dollar denominated assets and depreciates the dollar. Consequently, in times of global distress, the insurance claims paid by the US to the rest of the world decreases or increases according to the quality of US news, good or bad respectively.

Finally, our analysis does not fit well with the predictions of the scapegoat theory, which argues that the structural instability of macro parameters could lead rational investors to search for a "scapegoat" fundamental when their beliefs about the 
long-run value of the exchange rate conflict with the short-run movements (Bacchetta and van Wincoop, 2004, 2011). This theory suggests that the news about a particular macro variable can be picked as a scapegoat if the announced value is inconsistent with its long-run equilibrium, but in line with the observed direction of the exchange-rate movement. Hence, while our findings highlight the context-specific nature of the change in investors' reaction to news, scapegoat theory emphasizes the role of ad hoc shifts in investor focus.

\section{Exchange-rate volatility reaction to news}

In this section, we analyze the volatility response of exchange rates to macroeconomic news during our sample period. Previous literature finds that while the conditional mean return adjustment of exchange rates to news is very rapid, taking place within a few minutes, exchange rate return volatility adjusts to news only gradually, completing its full response in about an hour after the announcement (Andersen et al., 2003). Based on this result, we examine whether the sign switch effect we document in conditional mean returns has implications for the behavior of the second moments in a systematic manner.

To carry out the analysis, we perform a two-step weighted least square estimation procedure as described in Section 2, which includes the interactions of the news variables with the crisis and no-crisis dummy variables (Eq. (5)). Since volatility response is gradual, we report both the contemporaneous and the cumulative volatility response coefficients, which span a two-hour window following the announcements' release (Tables 11 and 12).

Overall, our results suggest that most announcements' volatility impact increased during the crisis. For instance, while a one standard deviation surprise increase in the Federal funds rate announcement increases euro return volatility by 62 basis points in expansionary periods, the same magnitude increase translates into an 89 basis point increase in volatility during the crisis period, an economically and statistically significant difference at the one percent level (Table 12). Volatility reaction to new home sales and housing starts is also stronger during the crisis. These findings suggest that the substantial increase in global uncertainty translated into a stronger and persistent volatility reaction to many macroeconomic news during the crisis period. Yet, there are a few exceptions to this result. For instance, we find that the payroll announcements and the jobless claims reports' impact on return volatility is stronger in good times than in bad times, a result evident in both the contemporaneous and the cumulative news response coefficients for all three major currency pairs.

Table 11

Volatility Model: US Contemporaneous News Response Coefficients (NBER recession dates: January 1, 2008 and June 30, 2009). This table presents the contemporaneous US news response coefficients from the variance model (Eq. (5)). For each currency pair, we run a pooled regression. The first (third) column presents the news surprise coefficients interacted with the crisis dummy (no-crisis dummy). Following the NBER, we define the crisis period as the interval between January 1, 2008 and June 30, 2009.

\begin{tabular}{|c|c|c|c|c|c|c|c|c|c|c|c|c|}
\hline \multirow[b]{2}{*}{ News variables } & \multicolumn{4}{|l|}{ USD/EUR } & \multicolumn{4}{|l|}{ USD/GBP } & \multicolumn{4}{|l|}{ USD/JPY } \\
\hline & No-crisis & $p$-val & Crisis & $p$-val & No-crisis & $p$-val & Crisis & $p$-val & No-crisis & $p$-val & Crisis & $p$-val \\
\hline Capacity utilization & 0.000 & 0.974 & 0.008 & 0.060 & 0.003 & 0.029 & 0.002 & 0.737 & 0.001 & 0.392 & -0.010 & 0.029 \\
\hline GDP advanced report & 0.035 & 0.000 & -0.001 & 0.703 & 0.030 & 0.000 & -0.011 & 0.007 & 0.033 & 0.000 & 0.010 & 0.016 \\
\hline GDP second report & 0.009 & 0.001 & 0.007 & 0.045 & 0.010 & 0.003 & 0.013 & 0.004 & 0.011 & 0.001 & 0.018 & 0.000 \\
\hline GDP third report & -0.003 & 0.117 & 0.004 & 0.263 & 0.000 & 0.953 & -0.002 & 0.679 & -0.012 & 0.017 & -0.022 & 0.026 \\
\hline Industrial production & 0.000 & 0.787 & -0.003 & 0.437 & -0.003 & 0.011 & 0.000 & 0.963 & 0.002 & 0.149 & 0.014 & 0.001 \\
\hline Personal income & 0.004 & 0.014 & -0.007 & 0.000 & 0.001 & 0.682 & -0.006 & 0.000 & 0.003 & 0.116 & -0.001 & 0.586 \\
\hline Retail sales & 0.015 & 0.000 & 0.010 & 0.000 & 0.017 & 0.000 & 0.008 & 0.002 & 0.019 & 0.000 & 0.019 & 0.000 \\
\hline New home sales & 0.005 & 0.000 & 0.010 & 0.083 & 0.003 & 0.029 & 0.004 & 0.548 & 0.010 & 0.000 & 0.020 & 0.012 \\
\hline Personal expenditure & 0.000 & 0.853 & 0.013 & 0.002 & 0.001 & 0.232 & 0.015 & 0.001 & 0.000 & 0.897 & 0.012 & 0.017 \\
\hline Business inventories & 0.002 & 0.085 & 0.007 & 0.000 & 0.001 & 0.281 & 0.002 & 0.217 & 0.001 & 0.446 & 0.010 & 0.000 \\
\hline Construction spending & 0.012 & 0.000 & 0.006 & 0.041 & 0.008 & 0.000 & 0.012 & 0.000 & 0.000 & 0.868 & 0.007 & 0.070 \\
\hline Durable orders & 0.006 & 0.000 & 0.030 & 0.000 & 0.004 & 0.005 & 0.021 & 0.000 & 0.007 & 0.000 & 0.023 & 0.000 \\
\hline Factory orders & 0.005 & 0.000 & 0.007 & 0.001 & 0.004 & 0.001 & 0.014 & 0.000 & 0.006 & 0.000 & 0.014 & 0.000 \\
\hline Consumer price index & 0.016 & 0.000 & 0.001 & 0.356 & 0.012 & 0.000 & 0.000 & 0.929 & 0.016 & 0.000 & 0.004 & 0.031 \\
\hline Producer price index & 0.004 & 0.001 & -0.009 & 0.000 & 0.003 & 0.072 & -0.002 & 0.650 & 0.004 & 0.025 & 0.008 & 0.022 \\
\hline Consumer confidence & 0.009 & 0.000 & 0.001 & 0.721 & 0.006 & 0.000 & 0.010 & 0.001 & 0.008 & 0.000 & 0.017 & 0.000 \\
\hline Housing starts & 0.004 & 0.000 & 0.005 & 0.029 & 0.003 & 0.027 & 0.001 & 0.747 & 0.004 & 0.012 & 0.034 & 0.000 \\
\hline ISM & 0.013 & 0.000 & 0.014 & 0.000 & 0.014 & 0.000 & 0.019 & 0.000 & 0.025 & 0.000 & 0.016 & 0.000 \\
\hline Leading indicators & 0.005 & 0.000 & 0.009 & 0.000 & 0.004 & 0.001 & 0.005 & 0.054 & 0.009 & 0.000 & 0.021 & 0.000 \\
\hline Initial claims & 0.008 & 0.000 & 0.006 & 0.000 & 0.005 & 0.000 & 0.002 & 0.104 & 0.008 & 0.000 & 0.010 & 0.000 \\
\hline Nonfarm payrolls & 0.070 & 0.000 & 0.036 & 0.000 & 0.068 & 0.000 & 0.039 & 0.000 & 0.070 & 0.000 & 0.033 & 0.000 \\
\hline Fed funds rate & 0.097 & 0.000 & 0.139 & 0.000 & 0.102 & 0.000 & 0.121 & 0.000 & 0.077 & 0.000 & 0.126 & 0.000 \\
\hline Trade balance & 0.027 & 0.000 & 0.002 & 0.399 & 0.022 & 0.000 & 0.004 & 0.178 & 0.022 & 0.000 & -0.003 & 0.438 \\
\hline \multirow[t]{2}{*}{ Treasury budget } & 0.000 & 0.804 & 0.000 & 0.250 & 0.000 & 0.799 & 0.000 & 0.655 & 0.000 & 0.099 & 0.001 & 0.041 \\
\hline & $\Omega$ Total & & $p$-val & & $\Omega$ Total & & $p$-val & & $\Omega$ Total & & $p$-val & \\
\hline Unscheduled News & 0.000 & & 0.000 & & 0.002 & & 0.000 & & 0.003 & & 0.000 & \\
\hline
\end{tabular}


Table 12

Volatility Model: US Cumulative News Response Coefficients (NBER recession dates: January 1, 2008 and June 30, 2009). This table presents the cumulative US news response coefficients from the variance model (Eq. (5)). The news coefficients are cumulated over the two hour window following the news release. For each currency pair, we run a pooled regression. The first (third) column presents the news surprise coefficients interacted with the crisis dummy (no-crisis dummy). Following the NBER, we define the crisis period as the interval between January 1, 2008 and June $30,2009$.

\begin{tabular}{|c|c|c|c|c|c|c|c|c|c|c|c|c|}
\hline \multirow[b]{2}{*}{ News variables } & \multicolumn{4}{|l|}{ USD/EUR } & \multicolumn{4}{|l|}{ USD/GBP } & \multicolumn{4}{|l|}{ USD/JPY } \\
\hline & No-crisis & $p$-val & Crisis & $p$-val & No-crisis & $p$-val & Crisis & $p$-val & No-crisis & $p$-val & Crisis & $p$-val \\
\hline Capacity utilization & -0.001 & 0.974 & 0.198 & 0.060 & 0.080 & 0.029 & 0.040 & 0.737 & 0.032 & 0.392 & -0.258 & 0.029 \\
\hline GDP advanced report & 0.363 & 0.000 & -0.013 & 0.703 & 0.316 & 0.000 & -0.109 & 0.007 & 0.347 & 0.000 & 0.105 & 0.016 \\
\hline GDP second report & 0.103 & 0.001 & 0.082 & 0.045 & 0.121 & 0.003 & 0.154 & 0.004 & 0.131 & 0.001 & 0.210 & 0.000 \\
\hline GDP third report & -0.043 & 0.117 & 0.059 & 0.263 & 0.002 & 0.953 & -0.024 & 0.679 & -0.179 & 0.017 & -0.323 & 0.026 \\
\hline Industrial production & -0.008 & 0.787 & -0.074 & 0.437 & -0.091 & 0.011 & 0.005 & 0.963 & 0.055 & 0.149 & 0.369 & 0.001 \\
\hline Personal income & 0.059 & 0.014 & -0.108 & 0.000 & 0.010 & 0.682 & -0.092 & 0.000 & 0.046 & 0.116 & -0.016 & 0.586 \\
\hline Retail sales & 0.189 & 0.000 & 0.126 & 0.000 & 0.215 & 0.000 & 0.097 & 0.002 & 0.240 & 0.000 & 0.242 & 0.000 \\
\hline New home sales & 0.055 & 0.000 & 0.108 & 0.083 & 0.030 & 0.029 & 0.041 & 0.548 & 0.106 & 0.000 & 0.213 & 0.012 \\
\hline Personal expenditure & 0.003 & 0.853 & 0.193 & 0.002 & 0.022 & 0.232 & 0.230 & 0.001 & -0.003 & 0.897 & 0.176 & 0.017 \\
\hline Business inventories & 0.027 & 0.085 & 0.114 & 0.000 & 0.018 & 0.281 & 0.038 & 0.217 & 0.014 & 0.446 & 0.164 & 0.000 \\
\hline Construction spending & 0.135 & 0.000 & 0.064 & 0.041 & 0.092 & 0.000 & 0.130 & 0.000 & 0.004 & 0.868 & 0.073 & 0.070 \\
\hline Durable orders & 0.078 & 0.000 & 0.398 & 0.000 & 0.049 & 0.005 & 0.281 & 0.000 & 0.094 & 0.000 & 0.306 & 0.000 \\
\hline Factory orders & 0.061 & 0.000 & 0.090 & 0.001 & 0.054 & 0.001 & 0.185 & 0.000 & 0.086 & 0.000 & 0.192 & 0.000 \\
\hline Consumer price index & 0.238 & 0.000 & 0.019 & 0.356 & 0.177 & 0.000 & -0.002 & 0.929 & 0.232 & 0.000 & 0.057 & 0.031 \\
\hline Producer price index & 0.055 & 0.001 & -0.136 & 0.000 & 0.039 & 0.072 & -0.022 & 0.650 & 0.053 & 0.025 & 0.119 & 0.022 \\
\hline Consumer confidence & 0.113 & 0.000 & 0.012 & 0.721 & 0.072 & 0.000 & 0.124 & 0.001 & 0.099 & 0.000 & 0.207 & 0.000 \\
\hline Housing starts & 0.059 & 0.000 & 0.086 & 0.029 & 0.045 & 0.027 & 0.016 & 0.747 & 0.060 & 0.012 & 0.550 & 0.000 \\
\hline ISM & 0.136 & 0.000 & 0.146 & 0.000 & 0.148 & 0.000 & 0.202 & 0.000 & 0.260 & 0.000 & 0.162 & 0.000 \\
\hline Leading indicators & 0.066 & 0.000 & 0.132 & 0.000 & 0.061 & 0.001 & 0.066 & 0.054 & 0.128 & 0.000 & 0.291 & 0.000 \\
\hline Initial claims & 0.109 & 0.000 & 0.087 & 0.000 & 0.062 & 0.000 & 0.029 & 0.104 & 0.115 & 0.000 & 0.138 & 0.000 \\
\hline Nonfarm payrolls & 0.661 & 0.000 & 0.344 & 0.000 & 0.644 & 0.000 & 0.372 & 0.000 & 0.661 & 0.000 & 0.311 & 0.000 \\
\hline Fed funds rate & 0.624 & 0.000 & 0.889 & 0.000 & 0.651 & 0.000 & 0.772 & 0.000 & 0.496 & 0.000 & 0.806 & 0.000 \\
\hline Trade balance & 0.315 & 0.000 & 0.022 & 0.399 & 0.256 & 0.000 & 0.045 & 0.178 & 0.256 & 0.000 & -0.029 & 0.438 \\
\hline Treasury budget & 0.002 & 0.804 & -0.026 & 0.250 & -0.002 & 0.799 & 0.010 & 0.655 & 0.026 & 0.099 & -0.078 & 0.041 \\
\hline
\end{tabular}

\section{Conclusion}

We examine an unusual episode in the behavior of the euro, pound and yen exchange rate markets when the dollar appreciated (depreciated) against the three major currencies, in response to unfavorable (favorable) US growth news during the global financial crisis. Contrary to the previous findings which suggest that the news effects switched sign indiscriminately for almost all major US macroeconomic indicators (Fratzscher, 2009), we show that only a handful of macro variables' effect reversed sign. In particular, announcements related to consumption, housing, labor and credit markets, which were at the epicenter of the crisis, exhibit sign asymmetry during this period, indicating a context-specific change in investors' reaction to news. The sign switch effect we document is present in all three markets, but weaker in the dollar-yen market.

We explore possible sources of the time variant exchange rate reaction to macro news over our sample period and consider the explanations suggested by the literature. In particular, we find that the fluctuation in the aggregate risk level is the primary factor driving the change in the news coefficient signs, specifically for consumption, real-estate and employment related news items. We find that, as market risk increases, the dollar appreciation in response to a unit of positive US growth news dampens. Fluctuations in carry trade returns matter mostly in the dollar-yen market.

Our findings highlight the context-specific nature of the change in investors' reaction to news and reveal that announcement chronology within an indicator category matters for the sign switch effect to take place. The documented sign reversal in news reaction is context-specific because, in a given month, only those announcements that are the earliest releases within an indicator category, which contain incremental information about consumption, real-estate and labor markets reveal sign asymmetry. Considering the sources and the evolution of risk during the 2008-2009 financial crisis, it is rational for investors to pay more attention to the signals in the earliest, most informative releases related to consumption, housing, credit and employment, with the goal of gleaning new information about the potential risks relevant to these factors.

Overall, we find that investor sentiment and economic conditions has an important impact on currency return behavior. During periods of elevated risk, traditional relationships between macroeconomic fundamentals and exchange rates may not hold. Investors and financial institutions that hold and trade international assets as well as the managers of non-financial corporations that participate in FX markets due to the nature and requirements of their businesses (such as importing, exporting and hedging activities) should take into account the time-variant nature of announcement effects. By enhancing our understanding of the behavior of exchange rates when there are significant fluctuations in risk conditions, this research may help managers anticipate the likelihood and magnitude of a news impact on exchange rates during periods of high uncertainty. It may also help traders and financial institutions improve their assessment of net returns on international assets that involve FX conversion by illuminating the forces behind investor expectations that drive the relationship between macroeconomic news and asset returns. 


\section{Acknowledgements}

The authors would like to thank Murray William and Peter Neczesny for providing the Hotspot FX data. We are indebted for useful comments and suggestions to Adel Bouslimi, Jens Hilscher, Carol Osler and Helen Rey as well as the participants at the 2013 Financial Management Association Meetings, the 2014 European Conference on Banking and the Economy, the Midwest Finance Association annual meeting in Orlando-USA, Paris Financial Management Conference in Paris-France, and the Multinational Finance Society annual meeting in Izmir-Turkey. Walid Ben Omrane acknowledges the financial support by the Social Sciences and Humanities Research Council of Canada (SSHRC).

\section{References}

Andersen, T.G., Bollerslev, T., Diebold, F.X., Vega, C., 2003. Micro effects of macro announcements: real-time price discovery in foreign exchange. Am. Econ. Rev. 93, 38-62.

Andersen, T.G., Bollerslev, T., Diebold, F.X., Vega, C., 2007. Real-time price discovery in stock, bond and foreign exchange markets. J. Int. Econ. 73 (2), 251277.

Bacchetta, P., van Wincoop, E., 2004. A scapegoat model of exchange rate determination. Am. Econ. Rev. Pap. Proc. 94, $114-118$.

Bacchetta, P., van Wincoop, E., 2011. On the unstable relationship between exchange rates and macroeconomic fundamentals, mimeo.

Bauwens, L., Ben Omrane, W., Giot, P., 2005. News announcements, market activity and volatility in the euro-dollar foreign exchange market. J. Int. Money Finance 24, 1108-1125.

Bekaert, G., Hoerova, M., Lo Duca, M., 2012. Risk, uncertainty and monetary policy Working paper. European Central Bank.

Boyd, J.H., Jagannathan, R., Hu, J., 2005. The stock market's reaction to unemployment news: why bad news is usually good for stocks. J. Finance 60, 649672.

Bruno, V., Shin, H.S., 2013. Capital flows and the risk-taking channel of monetary policy Working paper. Princeton University.

Cheung, Y., Chinn, M.D., 2001. Currency traders and exchange rate dynamics: a survey of the US market. J. Int. Money Finance 20, 439-471.

De Bock, R., De Carvalho Filho, I., 2013. The behavior of currencies during risk-off episodes Working paper, 12/8. IMF.

Dominguez, K.M., Panthaki, F., 2006. “What defines 'news' in foreign exchange markets? J. Int. Money Finance 25 (1), $168-198$.

Fatum, R., Hutchison, M., Wu, T., 2010. Asymmetries and state dependence. The impact of macro surprises on intraday exchange rates Working paper. University of Alberta.

Faust, J., Rogers, J.H., Wang, S., Wright, J.H., 2007. The high-frequency response of exchange rates and interest rates to macroeconomic announcements. J. Monetary Econ. 54, 1051-1068.

Federal Reserve Bank, 2011. Financial Turmoil Timeline <http://www. .newyorkfed.org/research/global_economy/policyresponses.html>.

Fratzscher, M., 2009. What explains global exchange rate movements during the financial crisis? J. Int. Money Finance $28,1390-1407$.

Goldberg, L., Grisse, C., 2013. Time variation in asset price responses to macro announcements: The role of risk Working paper. NBER, October, 19523.

Gourinchas, P., Rey, H., Govillot, N., 2010. Exorbitant privilege and exorbitant duty Working paper. London Business School.

Gürkaynak, R., Sack, B., Swanson, E., 2005. The sensitivity of long-term interest rates to economic news: evidence and implication for macroeconomic models. Am. Econ. Rev. 95 (1), 426-436.

Mancini, L., Ranaldo, A., Wrampelmeyer, J., 2013. Liquidity in the foreign exchange market: measurement, commonality, and risk premiums. J. Finance 68, $1805-1841$.

McCauley, R., McGuire, P., 2009. Dollar appreciation in 2008: Safe haven, carry trades, dollar shortage and overhedging. BIS Q. Rev., 85-93

McGuire, P., von Peter, G., 2009. The US dollar shortage in global banking and the international policy response. BIS Working paper, October, 291.

Melvin, M., Taylor, M.P., 2009. The crisis in the foreign exchange rate market. J. Int. Money Finance 28 (8), $1317-1330$.

Miranda-Agrippino, S., Rey, H., 2012. World asset markets and global liquidity Working paper. London Business School.

Neely, C.J., Dey, S.R., 2010. A survey of announcement effects on foreign exchange returns. Federal Reserve Bank St. Louis Rev. 92 (5), 417-463.

Rossi, B., 2006. Are exchange rates really random walks? Some evidence robust to parameter instability. Macroecon. Dyn. 10, 20-38.

Sarno, L., Valente, G., 2009. Exchange rates and fundamentals: footloose or evolving relationship? J. Eur. Econ. Assoc. 7, $786-830$.

Swanson, E.T., Williams, J.C., 2013. Measuring the effect of the zero lower bound on medium- and longer-term interest rates Working paper. Federal Reserve Bank of San Francisco.

Swanson, E.T., Williams, J.C., 2014. Measuring the effect of the zero lower bound on yields and exchange rates in the U.K. and Germany. J. Int. Econ. 92, 2-21. 